\title{
THE CHALCOLITHIC RADIOCARBON RECORD AND ITS USE IN SOUTHERN LEVANTINE ARCHAEOLOGY
}

\author{
Margie Burton • Thomas E Levy \\ University of California, San Diego, Department of Anthropology, 9500 Gilman Drive, La Jolla, California 92093, USA. \\ Email: mburton@weber.ucsd.edu and tlevy@ucsd.edu.
}

\begin{abstract}
Archaeological evidence suggests that the Chalcolithic period (5th-4th millennium BCE) in the southern Levant was a time of significant settlement expansion and increasing social complexity. Important technological and social developments during this era set the stage for the later rise of fortified sites and nascence of urbanization in the Early Bronze Age. Controversy surrounding the chronology of Chalcolithic settlement and the reconstruction of social trajectories has stimulated an interest in building a database of radiocarbon dates to measure the tempo of change and help resolve these issues. To facilitate social evolutionary research, this paper reviews and updates published ${ }^{14} \mathrm{C}$ data for the southern Levantine Chalcolithic. The now-substantial database supports the generally accepted time frame for this archaeological period and allows synchronic comparisons across diverse geographic subregions in the southern Levant. In addition, it helps to temporally place the emergence of sophisticated technologies and the development of complex social institutions within the Chalcolithic period. However, radiometrically based attempts at pan-regional internal periodization of the Chalcolithic and fine-tuning of protohistoric events such as site establishment and abandonment are frustrated by the lack of precision in ${ }^{14} \mathrm{C}$ dates, which limits their ability to resolve chronological sequence. Improved delineation of Chalcolithic social trajectories can be achieved most effectively by focussing research efforts on stratigraphic and typological investigations of deeply-stratified settlement sites such as Teleilat Ghassul and Shiqmim within their local contexts.
\end{abstract}

\section{INTRODUCTION}

The Chalcolithic period (5th-4th millennium BCE) in the southern Levant has attracted the interest of scholars since the 1920s. A growing corpus of archaeological evidence suggesting the development of new technologies (metallurgy, groundstone, agro-technology) and the elaboration of social institutions (public temples and formal burial grounds, craft specialization, settlement site hierarchies) reflects the dynamic nature of society at this time. The need to understand the sequence and tempo of Chalcolithic socioeconomic change that directly influenced the structure of Levantine urban societies in subsequent periods has contributed to an emphasis on building a data base of radiocarbon dates for this protohistoric era. Yet while the radiometric record is now substantial and provides a general time frame, it remains too coarse-grained to resolve sequences of social, political, and economic formations on its own. The purpose of this paper is then threefold: 1) to provide a current compendium of ${ }^{14} \mathrm{C}$ dates for the Chalcolithic period in the southern Levant, 2) to review the usefulness and limitations of these dates for the reconstruction of Chalcolithic social trajectories, and 3) to encourage renewed research focus on stratigraphic and typological studies within local contexts in order to illuminate patterns of societal development.

\section{Previous Reviews of the Southern Levantine ${ }^{14} \mathrm{C}$ Record}

J Lee (1973) and J Weinstein (1984) presented the first synthetic reviews of Chalcolithic ${ }^{14} \mathrm{C}$ dates for the Levant. By the 1990s the number of dates had grown significantly, establishing the groundwork for A H Joffe and J P Dessel's (1995) most recent summary of southern Levantine Chalcolithic chronology. They provided a very useful discussion of the dates available at that time and proposed an internal periodization for the southern Levant as a whole into "Early", "Developed", and "Terminal" Chalcolithic based primarily on the ${ }^{14} \mathrm{C}$ evidence. However, the clustering of dates for the "Developed" and "Terminal" Chalcolithic observed by Joffe and Dessel (1995) seems to rely largely on the use of date range midpoints. When more properly treated as probabilistic ranges, the ${ }^{14} \mathrm{C}$ dates exhibit considerable overlap. Furthermore, because Joffe and Dessel's paper included an edited list of the dates available from Chalcolithic and late Pottery Neolithic sites in Israel, Egypt,

(C) 2001 by the Arizona Board of Regents on behalf of the University of Arizona

Near East Chronology: Archaeology and Environment. RADIOCARBON, Vol 43, Nr 3, 2001, p 1223-1246

Proceedings of the 17 th International ${ }^{14} \mathrm{C}$ Conference, edited by $\mathrm{H}$ J Bruins, I Carmi, and E Boaretto 
and Jordan at the time of publication (1995:509-510, Table I), it did not comprise a complete record of the radiometric evidence for the entire southern Levant. Their phasing scheme appears to be focused on the Mediterranean and Irano-Turanian climatic zones, which have produced the majority of the published ${ }^{14} \mathrm{C}$ dates for the Chalcolithic period. Explicitly omitted were dates from SaharoArabian arid zone regions of Israel and Sinai (Avner et al. 1994). ${ }^{14} \mathrm{C}$ data from these seemingly hostile environments suggest long-term, continuous human habitation and, in some cases, apparently conservative desert socioeconomic adaptations from the Late Neolithic through the Early Bronze Age that are incompatible with Joffe and Dessel's tri-partite subdivision of the Chalcolithic. Finally, the subphased temporal framework they propose has limited capacity for evaluating social processes, including as it does a ca. 800-year time span (4500-3700 BCE) for the "Developed" Chalcolithic.

In 1994, I Gilead reviewed ${ }^{14} \mathrm{C}$ dates for the Nahal Beersheva vicinity (Irano-Turanian semi-arid zone) sites of Horvat Beter, Safadi, and Shiqmim in an attempt to more finely delineate their chronological relationship. He presented a "short duration" hypothesis for Shiqmim, in which settlement may have been limited to " $\ldots$ one or two centuries around 4300 and 4200 BC", preceding the occupations of Horvat Beter and Safadi (Gilead 1994:7). This suggestion was based on an averaging of the complete sets of dates for Horvat Beter and Safadi and of the interquartile range of dates from Shiqmim (Gilead 1994:6). Such a procedure may be used to narrow the sigma spread for a cluster of statistically similar dates from the same archaeological context. Assuming that the relatively few dates from Horvat Beter (3; C-919 was omitted from the calculation) and Safadi (7) adequately sample their respective settlement periods, this exercise seems to bring the timing of occupation at these two sites into better focus at the turn of the 5th millennium, between about 4000 and $3900 \mathrm{BCE}$ (one sigma range; Gilead 1994:4). However, as Gilead points out, when all the Shiqmim dates are considered along with their sigma ranges, one cannot reject the alternative that the settlements of Horvat Beter and Safadi may have been contemporary with that of Shiqmim, and that the duration of occupation at Shiqmim may have spanned and exceeded that of the other two sites (Gilead 1994:7). Evaluation of these different settlement scenarios must rely on stratigraphic and artifactual analysis (Gilead 1994:11). Similarly, assertions that all three sites were abandoned by 3800 BCE and that the Nahal Mishmar treasure was significantly later than habitation at these northern Negev sites cannot be confirmed on the basis of the available ${ }^{14} \mathrm{C}$ dates alone. The sigma ranges make it exceedingly difficult to chronologically pinpoint short-term events precisely.

These recent radiometrically based syntheses of Chalcolithic chronology and attempts to reconstruct settlement sequences have been unsatisfactory or inconclusive largely because ${ }^{14} \mathrm{C}$ dates, which represent ranges within which the true date of the sampled material probably falls, have limited ability to refine site contemporaneity and phasing across the southern Levant within the approximate thousand-year time span of the Chalcolithic. They can provide only gross chronological resolution. Stratigraphy and typological associations, however, can potentially contribute to finer-grained chronologies (Gilead 1994:11; Marcus and Feinman 1998:12). Thus, deeply stratified sites with superimposed floors and buildings, such as Teleilat Ghassul and Shiqmim, hold the key to better understanding of social developmental processes during the Chalcolithic. Because the tempo and nature of social trajectories may differ from subregion to subregion, sequencing must be constructed within local, rather than pan-regional, contexts. To facilitate such research, this paper provides a complete list (updated through 1999) of ${ }^{14} \mathrm{C}$-dated 5th-4th millennium Late Neolithic/Early Chalcolithic and Chalcolithic sites in the southern Levant arranged by geographic subregion. Brief descriptions of dated occupation phases at Teleilat Ghassul and Shiqmim are presented as examples of the kind of intrasite diachronic studies needed to investigate social evolutionary sequences. On-going research 
at these sites, coupled with new dates and contextual information from other recently excavated sites such as Gilat, Peqi'in Cave, Cave of the Warrior, Nahal Qanah Cave, and Abu Hamid should lead to improved temporal resolution of social evolutionary processes in the southern Levant during the Chalcolithic period.

\section{METHODS}

We have included in our compilation all available (through 1999) ${ }^{14} \mathrm{C}$ dates for sites in Israel, Jordan, and Sinai with artifact assemblages identified as belonging to Late Neolithic/Early Chalcolithic (Wadi Raba and Wadi Raba variants following Gopher and Gophna 1993) or Chalcolithic cultural complexes (see map in Figure 1). (Four 6th millennium calibrated BCE dates for Ard Tlaili in the Beqqa Valley of Lebanon, representing the northernmost extension of the Wadi Raba Late Neolithic/ Early Chalcolithic cultural entity, are not included here. These are given in Gopher and Gophna (1993:305). In the case of desert regions such as southern Jordan, the southern Negev, and Sinai where many dates are from tumuli fields and assemblages and typological parallels are sparse, we have selected dates from those sites which fall within the chronological range established by excavated and dated sites with recognized Late Neolithic/Chalcolithic and Chalcolithic material assemblages. The aim here is to create an inclusive picture of broadly contemporaneous occupied areas in the southern Levant within which synchronous socioeconomic trajectories may be examined and compared. To provide as complete a radiometric record as possible, we have avoided editing dates beyond these general parameters.

The entire corpus of dates is presented in two formats. A table of the dates, organized by site and geographic region, is presented in the appendix and includes uncalibrated BP and calibrated BCE 1sigma (68\% probability) and 2-sigma (95\% probability) ranges. Published BP dates have been calibrated using the CALIB 4.0 Radiocarbon Computer Program (Rev. 4.1.2) based on INTCAL98 data (Stuiver et al. 1998). Figure 2 shows the calibrated BCE date ranges (thick bar $=1$-sigma range; thin $\mathrm{bar}=2$-sigma range) from all dated sites in chronological order. This provides a visual impression of the overall temporal framework of Chalcolithic society for the region as a whole.

\section{RESULTS AND DISCUSSION}

\section{Building a Chronological Framework for the Chalcolithic of the Southern Levant}

Examination of Figure 2 reveals that the 2-sigma ranges of most of the ${ }^{14} \mathrm{C}$ dates fall entirely within the 5th and 4th millennia BCE, substantiating the generally accepted time frame for the Chalcolithic cultural entity. Dates that extend into the 6th millennium BCE are primarily from sites or strata identified on the basis of their assemblages as Late Pottery Neolithic, Jericho IX/Lodian, Qatifian, or Wadi Raba (normative or variant) entities. These include Nahal Qanah Cave Late PN level, Tel Tsaf, Newe Yam, Kfar Samir, Nizzanim, Teleilat Ghassul II/III, Abu Hamid basal levels, Peqi'in Cave Wadi Raba and pre-Ghassulian levels, Tel Wadi Fidan Profile B, Nahal Issaron, Uvda 7, Megadim, Tel Hreiz, Givat Haparsa, and Qatif Y-3 (see Gopher and Gophna 1993 for classification). Conversely, Jericho IX/Lodian, Qatifian, and Wadi Raba sites/strata only rarely yield dates with 2-sigma ranges extending later than the mid-5th millennium (Ein el Jarba GX-786 and GX-787, Givat Haparsa?, Newe Yam HV-4256?, Kfar Samir RT-70 and RT-1929A). Thus, the preponderance of the available radiometric and stratigraphic evidence suggests that the Chalcolithic proper emerged during the first half of the 5th millennium BCE. Late Pottery Neolithic material culture appears to have been largely supplanted by identifiably Chalcolithic assemblages in many parts of the southern Levant no later than $4500 \mathrm{BCE}$. 


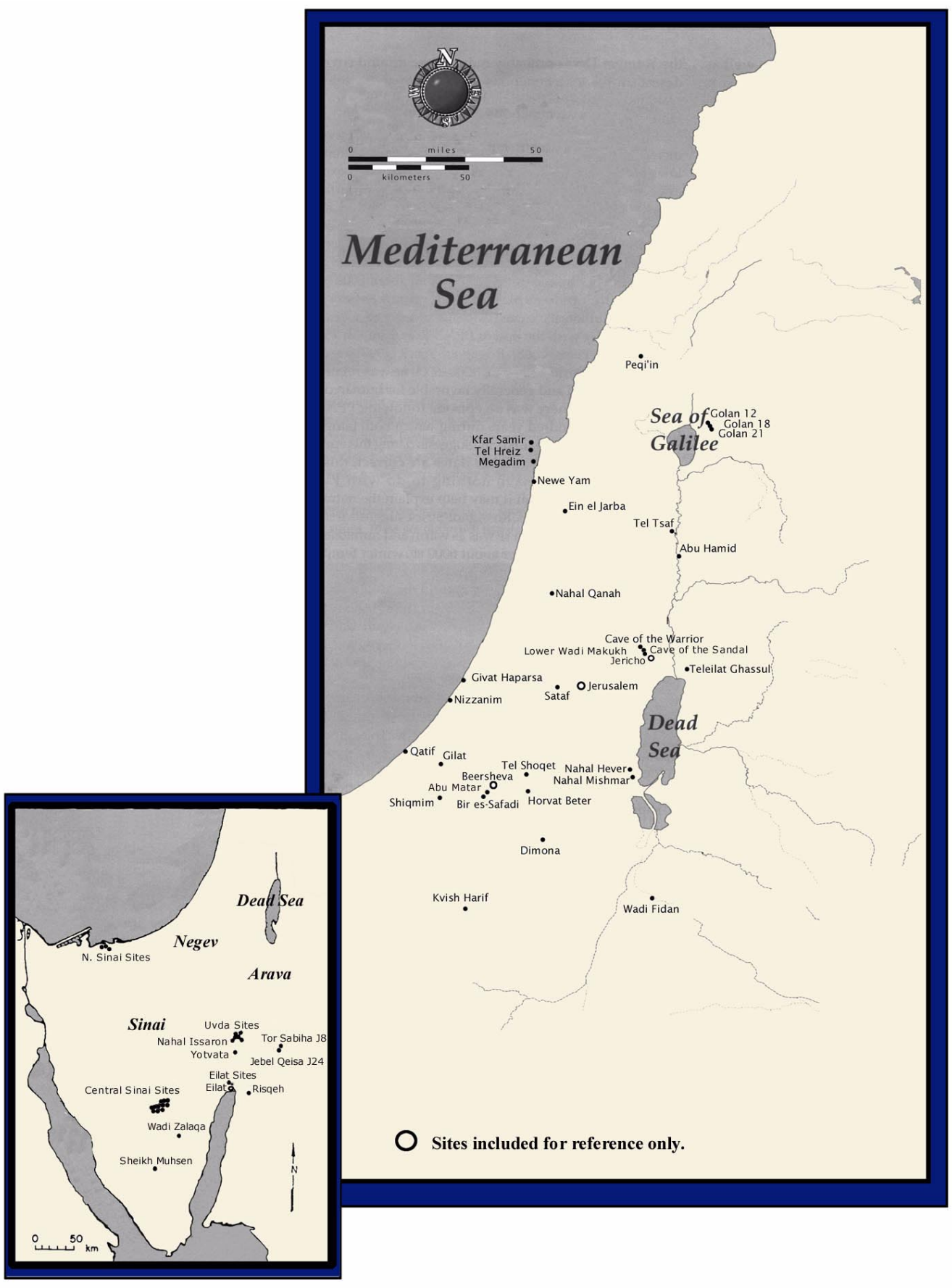

Figure 1 Map of Late Neolithic/Early Chalcolithic and Chalcolithic sites with ${ }^{14} \mathrm{C}$ dates 


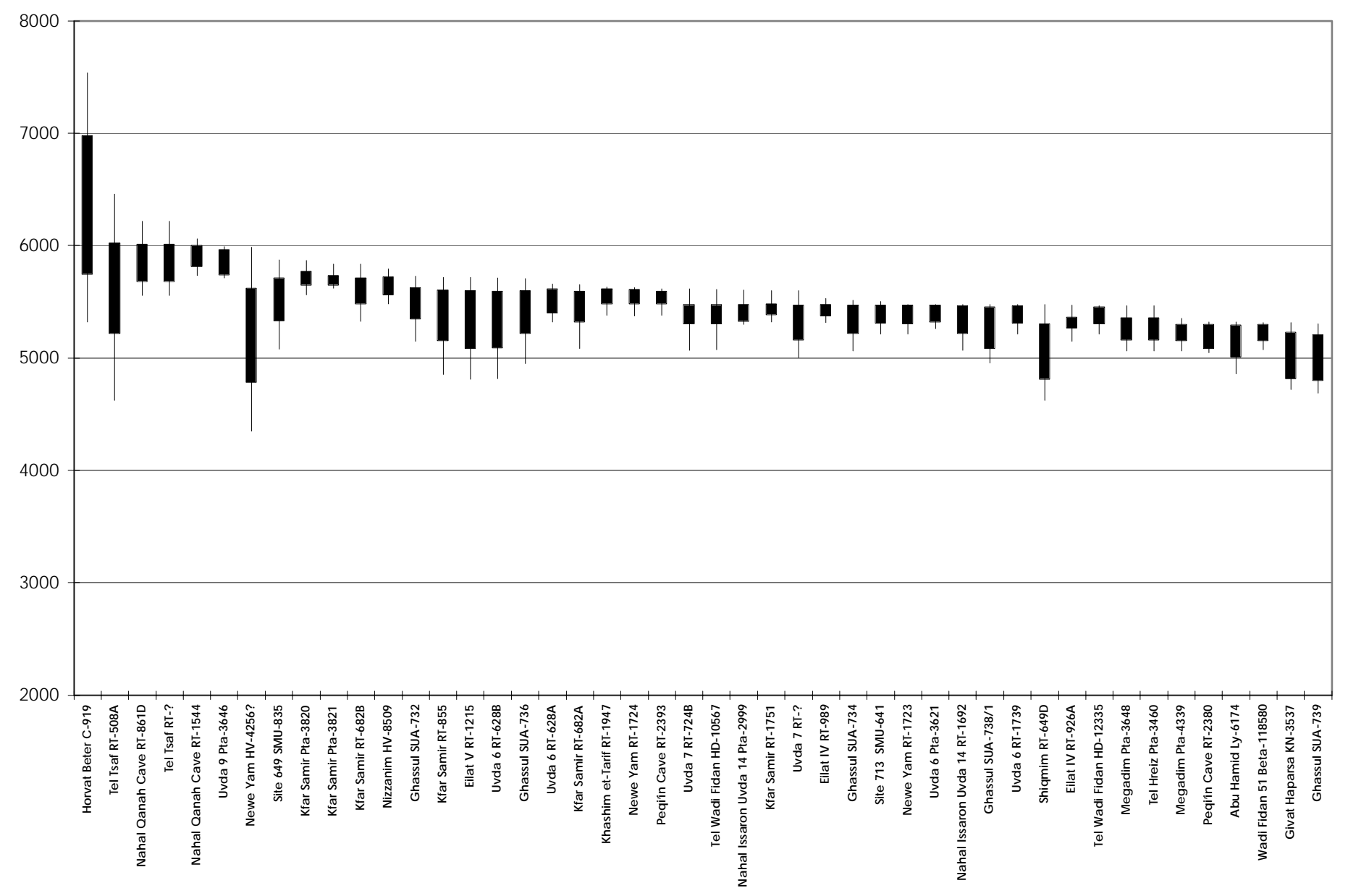

Figure 2 (1 of 5) Calibrated ${ }^{14} \mathrm{C}$ dates for Late Neolithic/Early Chalcolithic and Chalcolithic sites in the Southern Levant 


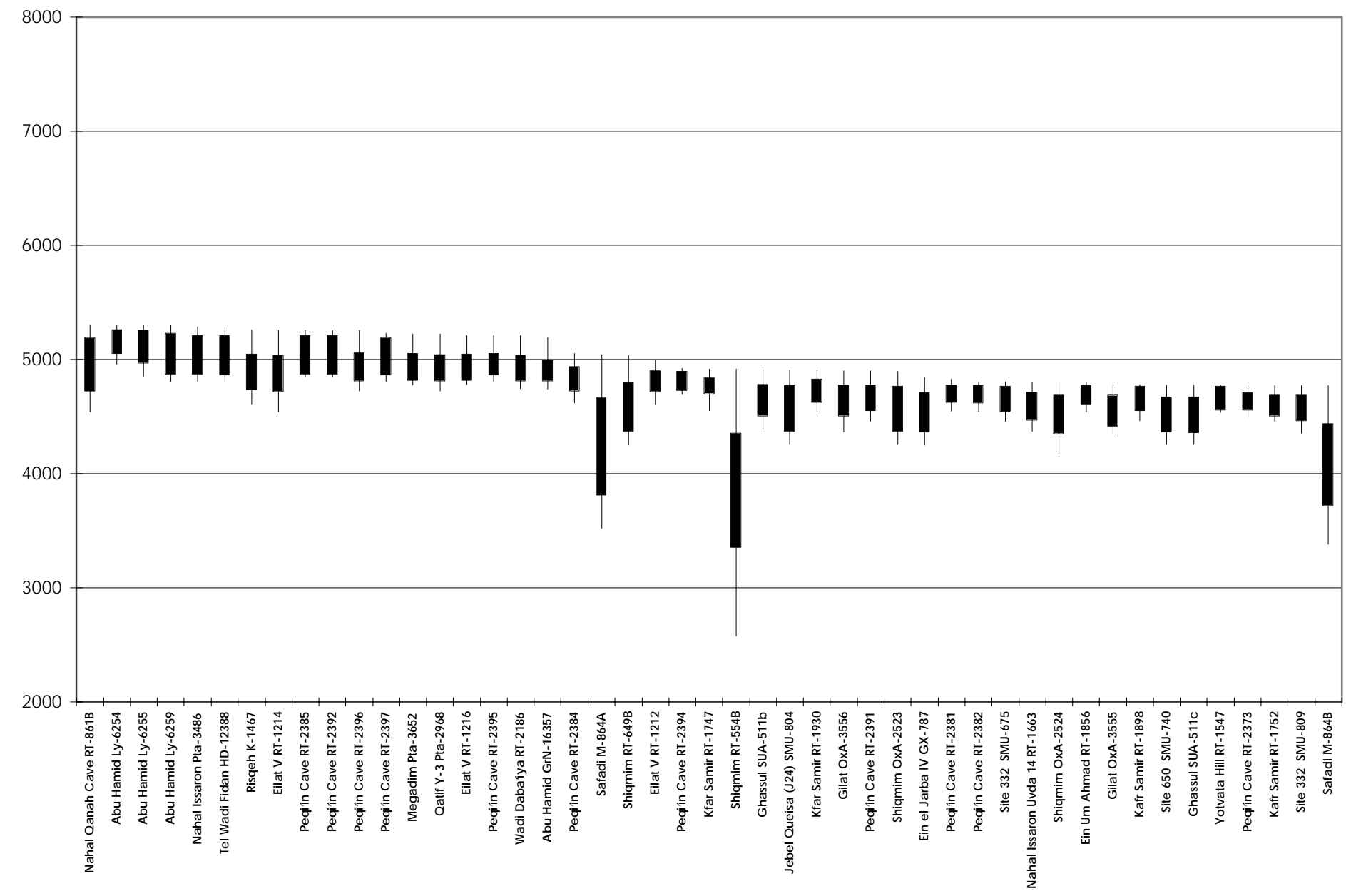




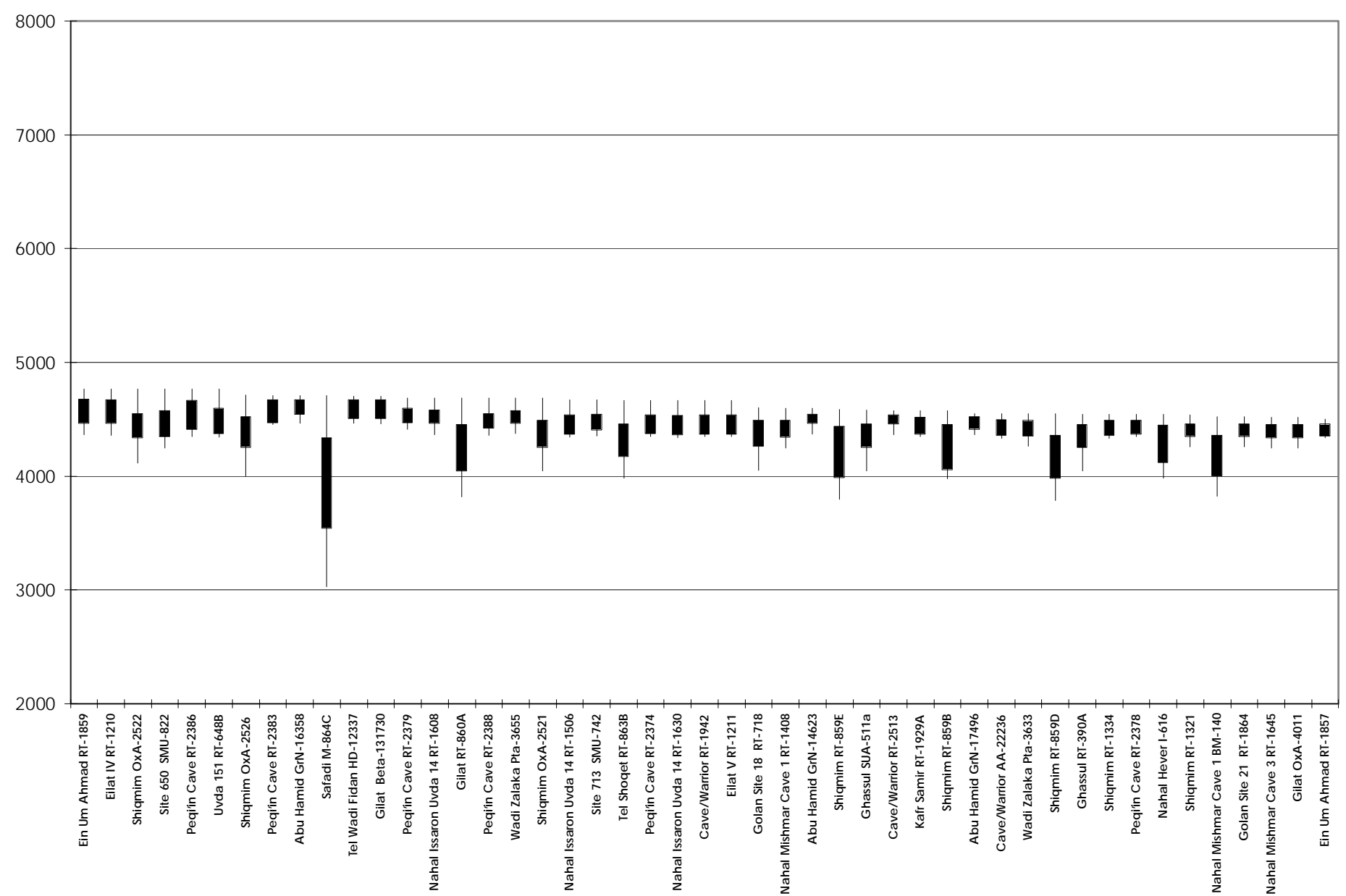




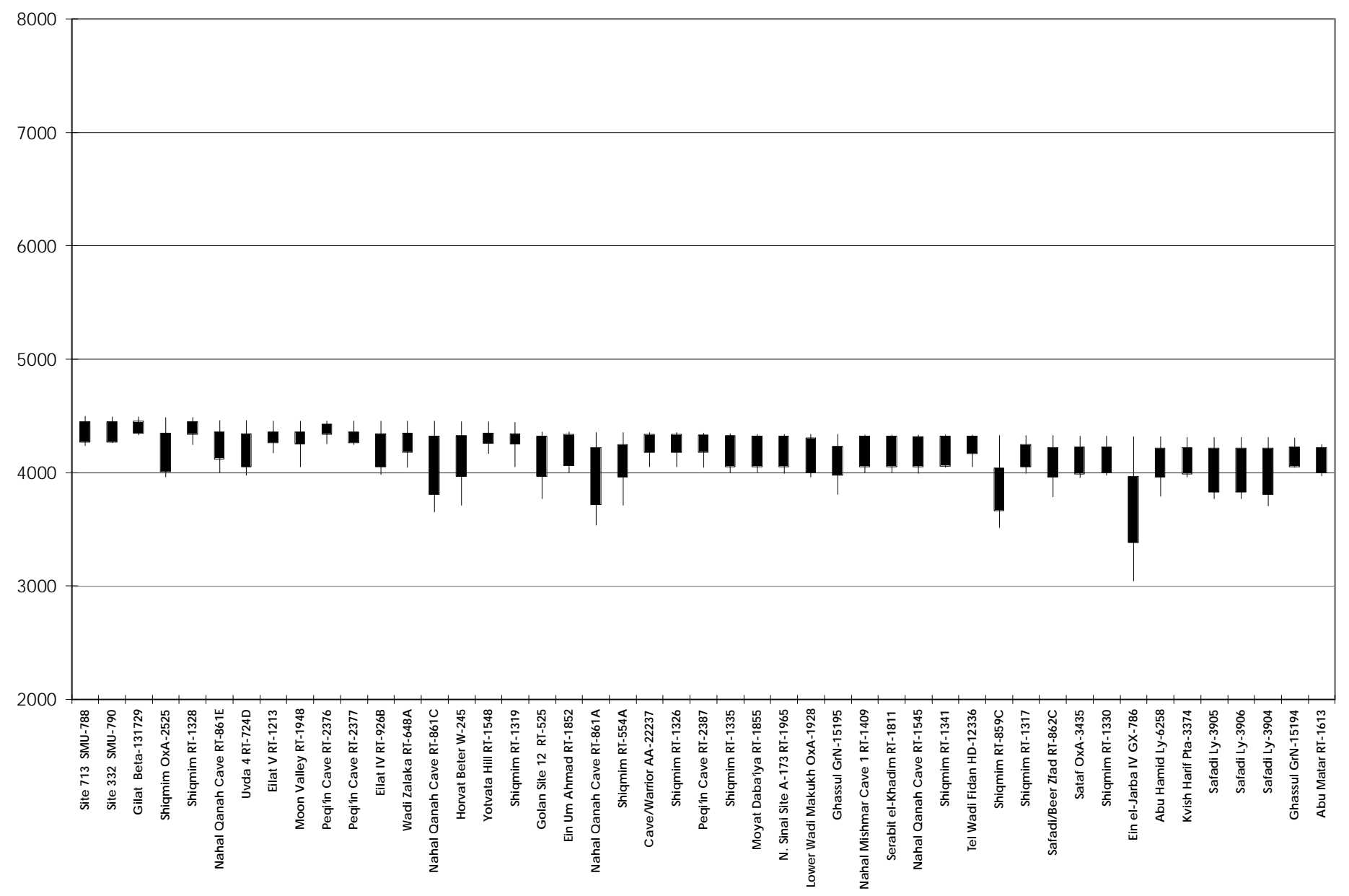

Figure 2 (Continued; 4 of 5) 


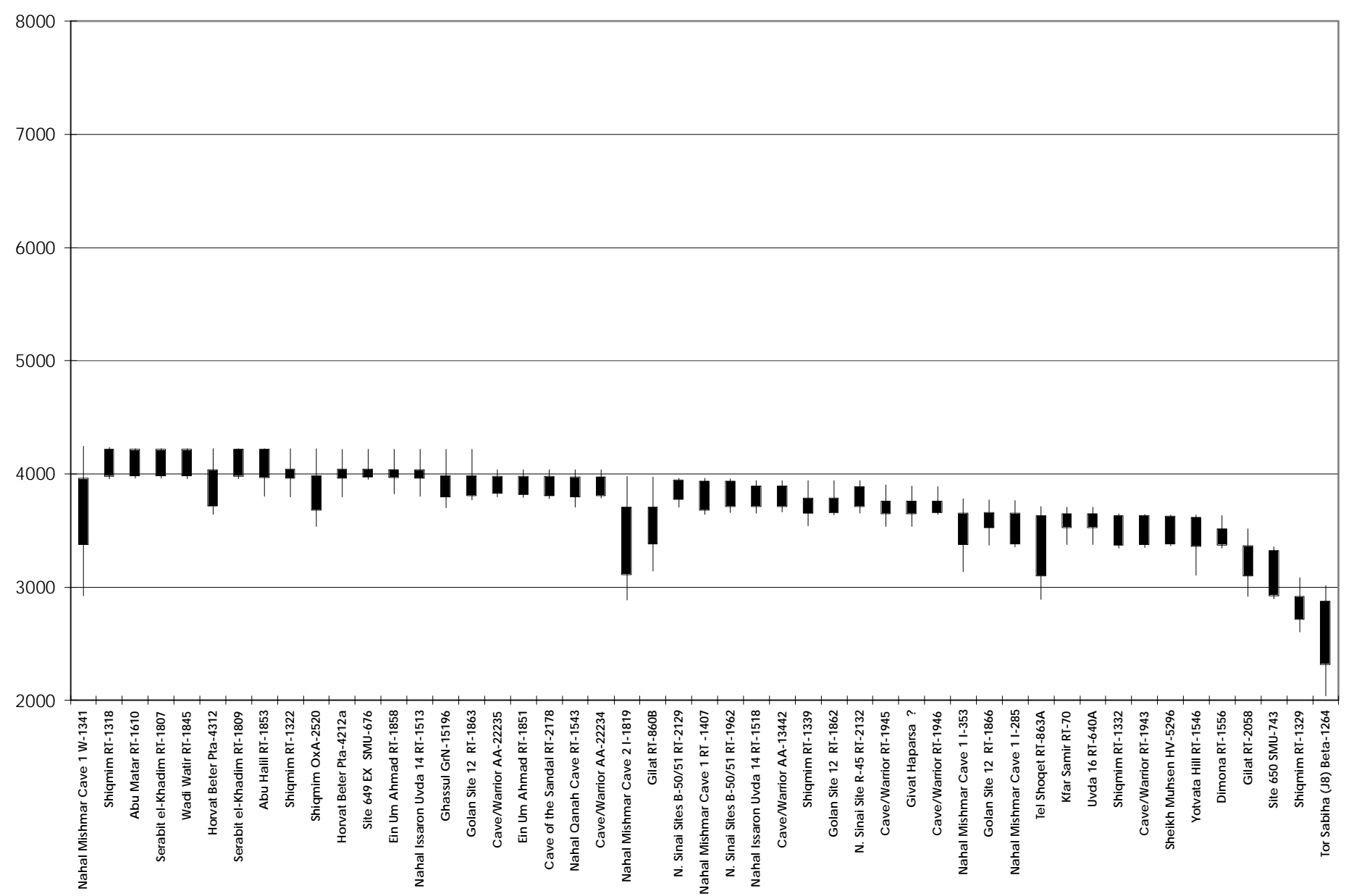

Figure 2 (Continued; 5 of 5) 
The end of the Chalcolithic period-the Chalcolithic/Early Bronze I (Early EB I or EB IA) transition-has been described as a case of social, political, economic, and demographic collapse (Gophna 1998). Gaps in our knowledge probably serve to accentuate apparent disjunctions in settlement patterns and artifact assemblages. Still, current stratigraphic and radiometric evidence indicates that most large Chalcolithic sites were abandoned by the mid-4th millennium BCE and not resettled, although some may have had limited and ephemeral occupation extending into what may be termed the Early Bronze IA (EB IA). It is difficult at present to temporally place this cultural horizon more precisely, and concerted research efforts are needed on this subject. Known, welldescribed sites with stratified Chalcolithic/EB IA sequences are rare. The problem is exacerbated by the relatively few published ${ }^{14} \mathrm{C}$ dates from southern Levantine sites that span the centuries from about 3600 to 3200 BCE. Only Golan Site 12 (RT-1866), Cave of the Warrior (RT-1943), Nahal Mishmar (W-1341, I-353, I-285, I-1819), Shiqmim (RT-1332, RT-1329), Gilat (RT-860B, RT-2058), and Tel Shoqet (RT-863A) have thus far yielded dates that range into the late 4th millennium BCE from clearly-defined Chalcolithic cultural contexts.

The validity of some of these previously published late dates now in fact seems questionable, with new testing of the Nahal Mishmar "Treasure" mat suggesting a 5th millennium BCE date (Aardsma 2001). Braun's (1996:155-70) review of late 4th millennium BCE ${ }^{14} \mathrm{C}$ dates from early EB I sites, many of which are from tombs used for considerable spans of time, outlines the significant interpretation problems inherent in that corpus of dates. Some new ${ }^{14} \mathrm{C}$ dates from settlement sites identified as early EB I (e.g. Afridar Area G: E Braun [personal communication], and Ashqelon: Segal and Carmi [1996:91] on Israel's Coastal Plain; Wadi Fidan 4 in Jordan: Adams and Genz [1995:19]) imply that the beginning of this period could be placed at around $3600 \mathrm{BCE}$, earlier than previously thought. Other very recent information-such as new AMS determinations from Teleilat Ghassul (Bourke et al. 2001) - seems to corroborate an early 4th millennium BCE denouement of the Chalcolithic, at least in some subregions (cf. Gilead 1994:11).

Such a "high chronology" would be consistent with the early work of J Mellaart (1979:19; Figure 1), whose synthesis of Near Eastern historical and ${ }^{14} \mathrm{C}$ chronologies posited the beginning of Palestine's $\mathrm{EB}$ at around $4000 \mathrm{BCE}$ (see also Lee 1973). Yet firm conclusions in this regard require an evaluation of the late dates from the Golan, Cave of the Warrior, Gilat, Tel Shoqet, and Shiqmim. Furthermore, the final occupation levels of Shiqmim were inadequately sampled and additional dates from this site are needed to clarify a local Beersheva valley Chalcolithic terminus. Forthcoming reports on Nahal Tillah/Halif Terrace, one of very few habitation sites with continuous stratified occupation sequences from the Chalcolithic into the late Early Bronze Age (EB IB), may also contribute to chronological and typological delineation of this transition (cf. Levy et al. 1997). Even as more evidence comes to light it should be acknowledged that absolute chronological boundaries between archaeological periods, which represent taxonomic constructs imposed on social developmental continua, are likely to remain shifting and locally defined.

An internal periodization of the main Chalcolithic time period (ca. 4500-3600 BCE) continues to be elusive despite the more than $200{ }^{14} \mathrm{C}$ dates now available. The lack of obvious gaps in Figure 2's chronologically arranged sequence of dates suggests that there is no occupational lacuna within the southern Levantine Chalcolithic as a whole. There is no apparent clustering of dates when the sigma ranges are considered. Furthermore, the general homogeneity and stability of Chalcolithic material culture has so far offered little in the way of high-resolution temporal markers. Thus, pan-regional subdivisions of the period proposed on the basis of ${ }^{14} \mathrm{C}$ dates and uneven typological evidence, such as Joffe and Dessel's (1995) "Developed" and "Terminal" Chalcolithic, seem premature. Attention should be directed instead toward detailed studies of sites on a subregional basis. Gilead's (1994:11- 
2) effort to reconstruct the history of Beersheva valley Chalcolithic settlement, though inconclusive and hindered by the incomplete stratigraphic and artifactual data available for some of the sites involved, provides an example of the spatial and analytical scale needed to delineate social trajectory.

\section{Reconstructing Subregional Social Trajectories}

The geographically-arranged table of ${ }^{14} \mathrm{C}$ dates (Appendix) facilitates chronological comparisons within and across subregions of the southern Levant. Detailed discussion of each set of dates is beyond the scope of this paper. However, some general observations may be made that serve to illustrate the usefulness as well as the limitations of the ${ }^{14} \mathrm{C}$ data.

First, it is clear from the radiometric record that a variety of environmental zones were occupied during the 5th-4th millennium BCE. Chalcolithic societies were distributed throughout most areas of the southern Levant including the Golan, the Galilee, Samaria, the Judean mountains, the Judean desert, the Jordan valley, the northern, central, and southern Negev desert, southern Jordan, and the Sinai peninsula. ${ }^{14} \mathrm{C}$ dates play an especially important role in determining chronological parameters for settlement in extreme arid zones such as the southern Negev and Sinai where human habitation was previously thought to have been intermittent or absent before the beginning of the Bronze Age (Avner et al. 1994: 267; Rothenberg and Glass 1992:141). This is because relative dating of desert sites, many of which are cult or burial sites, is complicated by re-use over long periods by many social groups, frequently sparse artifact assemblages, and lack of typological parallels with material culture from more humid parts of the Levant. Scholars have identified the Timnian complex, a tool kit adapted to desertic economic strategies, as a dominant material tradition in southern Jordan, the southern Negev, and Sinai, in contrast to the Ghassulian/Beersheva complexes of regions to the north (Henry 1995:353-4; Kozloff 1974:47-8; Rothenberg and Glass 1992:145).

${ }^{14} \mathrm{C}$ data for Timnian sites in Sinai and southern Jordan indicate a very wide chronological range (6th-3rd millennium BCE), which suggests a relatively slow rate of technological change in these arid zone assemblages and a developmental trajectory that was to some extent independent of that experienced in better-watered areas of the southern Levant (Rothenberg and Glass 1992:152). Meanwhile Avner (1998) has recently outlined a developmental sequence for sites in the Uvda valley, in the southernmost Negev, that corresponds to the traditional Late Neolithic-Chalcolithic-Early Bronze Age classification. The Uvda valley seems to have experienced relatively high population densities throughout the 6th-3rd millennia BCE compared to other desert areas and, based on an analysis of changes in architecture and artifacts, an evolution from hunter-gatherer to desert agricultural economies (Avner 1998:188). Thus, while other kinds of archaeological evidence are needed to clarify the details of socio-economic process and possible interaction among Levantine subregions, ${ }^{14} \mathrm{C}$ dates have contributed greatly to our ability to identify such broadly synchronous yet divergent social patterns between and within different environmental zones.

Second, ${ }^{14} \mathrm{C}$ dates from a number of sites have helped to chronologically place significant technological and social innovations within the Chalcolithic period. For example, ossuaries and rich grave goods, including gold ingots, were found in association with child and adult skeletal remains in the Chalcolithic level at Nahal Qanah Cave and dated to the late 5th-early 4th millennium BCE (RT861 A, RT-861C, RT-861E, RT-1545) (Gopher 1996:217). ${ }^{14} \mathrm{C}$ dates for the Nahal Mishmar Cave "Treasure"- a unique cache of fine carved ivory and manufactured copper maceheads, standards, and "crowns"- are too imprecise to pinpoint the deposition event (BM-140, W-1341, I-285, and I353 are associated with the "treasure" itself; see Bar-Adon 1980:199, 216; see also new dates, Aardsma 2001). They do, however, securely place the manufacture of these technologically sophisticated items within the main Chalcolithic time frame, providing independent corroboration of the 
original attribution based on artifact parallels. Specialized metallurgy, prestige objects, and the association of rich grave goods with child burials are important archaeological correlates of complex society. Their ${ }^{14} \mathrm{C}$ dating to this time period lends support to models that posit the emergence of social inequality in some parts of the southern Levant during the Chalcolithic. Additional radiometric, stratigraphic, and other archaeological evidence is needed to more finely resolve the tempo of these social processes within the Chalcolithic period.

Finally, it should be recognized that in certain archaeological contexts and depending on the rate of stylistic change, ${ }^{14} \mathrm{C}$ dates may not always be helpful in distinguishing chronological trends in artifact assemblages and cultural differentiation. This is especially true in the case of burial caves which may have been used by different social groups and where earlier deposits may be disturbed by later interments. Peqi' in Cave, discovered in the Galilee in 1995, has yielded $22{ }^{14} \mathrm{C}$ dates from Early Chalcolithic (dwelling) and Ghassulian Chalcolithic (burial) levels (Segal et al. 1998). The numerous artifacts, including elaborate ossuaries found in disarrayed burial contexts, show clear links with other, better known areas of Chalcolithic settlement, including the Golan, the Jordan valley, the Coastal plain, the Judean desert, and the northern Negev. This diverse collection at a single site is unique and may be interpreted as representing a chronological development. Alternatively, the finds may be the products of a previously unrecognized, syncretistic Upper Galilee Chalcolithic culture. It is also possible that the cave served as a common burial site for social groups from different areas thus providing evidence of the co-existence of these subregional Chalcolithic cultures (Gal et al. 1997:154, 1999:15). The ${ }^{14} \mathrm{C}$ dates do not help sort out these different interpretations, indicating only that the main Chalcolithic period of use occurred between about 4500 and 4000 BCE. The Cave of the Warrior in the northern Judean desert near Jericho presents a somewhat different case. ${ }^{14} \mathrm{C}$ dates confirmed the chronological sequencing of two superimposed burials as "Ghassulian Chalcolithic" and "late Chalcolithic" (Jull et al. 1998:111). Unfortunately, and despite the remarkable nature of the preserved perishable artifacts such as straw mats, fine textiles, and wooden implements, the lack of pottery and flint makes it difficult to establish links with most settlement sites. Recognizable and widely distributed typological markers correlated with reliable stratigraphy are needed in order to extrapolate chronological sequencing from site to site. Therefore, while artifacts from these Chalcolithic burial caves are interpreted as providing evidence of social ranking (Gal et al. 1999:14; Schick 1998:19-22) and suggest the possibility of interaction between distinct social groups-and the ${ }^{14} \mathrm{C}$ dates place this activity in the 5th-4th millennium BCE, evolutionary trajectories must be charted primarily on the basis of well-stratified settlement sites within their subregional cultural contexts.

\section{Studying Deeply Stratified Sites: Teleilat Ghassul and Shiqmim}

Teleilat Ghassul in Jordan's Dead Sea valley and Shiqmim in Israel's northern Negev desert are the two most deeply stratified Chalcolithic settlement sites now known in Palestine. Continuing investigation of stratigraphic and typological sequences at these sites can potentially provide the key to understanding social evolutionary change in their respective subregions.

A series of intermittent excavations at Teleilat Ghassul, beginning in 1929 and renewed by the University of Sydney in the 1990s, has revealed at least ten major building phases with over 100 successive floor levels extending from the late Pottery Neolithic through the main phase of the Chalcolithic. The $12{ }^{14} \mathrm{C}$ dates available in 1999 for Teleilat Ghassul are shown in Figure 3. According to Bourke (1997:410-1), the earlier set of five dates (SUA-732, 734, 736, 738/1, 739) corresponds to Ghassul's "Middle" or "pre-Classic" phase (Hennessy Phase G-E), and thus does not represent Neolithic assemblages (Hennessy Phase I-H) but rather what may be termed "Early Chalcolithic" (see also new 
AMS dates for this phase in Bourke et al. 2001). Middle Phase ceramic finds include the first appearance of churns, cornets, and fenestrated stand vessels (Bourke 1997:407-8). Bourke notes that despite the overlap in ${ }^{14} \mathrm{C}$ dates from other Late Neolithic/Early Chalcolithic assemblages, ceramic parallels can be drawn only with the pottery of nearby Tel Tsaf, also in the Jordan valley. The "Classic Ghassulian" or "Late Phase" levels at Teleilat Ghassul are sampled radiometrically by seven dates (SUA-511a,b,c; RT-390A; and GrN-15194, 15195, 15196). Taken conservatively, these dates suggest that fully developed Chalcolithic material at Teleilat Ghassul—marked by sanctuary architecture and a significant degree of specialization and refinement in art and manufactured goods-probably falls within a time frame of approximately 4900-3700 BCE, broadly contemporaneous with similar developments exemplified in northern Negev assemblages. While the dates are extremely important in terms of confirming general stratigraphic-typological sequence at Ghassul, the sample of seven shown here (with overlapping sigma values) may be too small and imprecise to define possible occupation horizons within the Classic Ghassulian phase at the site. In 1997, Bourke (1997:411) commented that the dated samples did not represent either the earliest or the latest Classic Ghassulian strata and that Chalcolithic settlement at Teleilat Ghassul may have continued well into the mid-4th millennium BCE. More recently, he has proposed a final date of around $4000 \mathrm{BCE}$ for significant Chalcolithic occupation at the site (Bourke et al. 2001). Additional ${ }^{14} \mathrm{C}$ dates and detailed material analyses from this key site should help to clarify Chalcolithic social trajectory in the Jordan Valley.

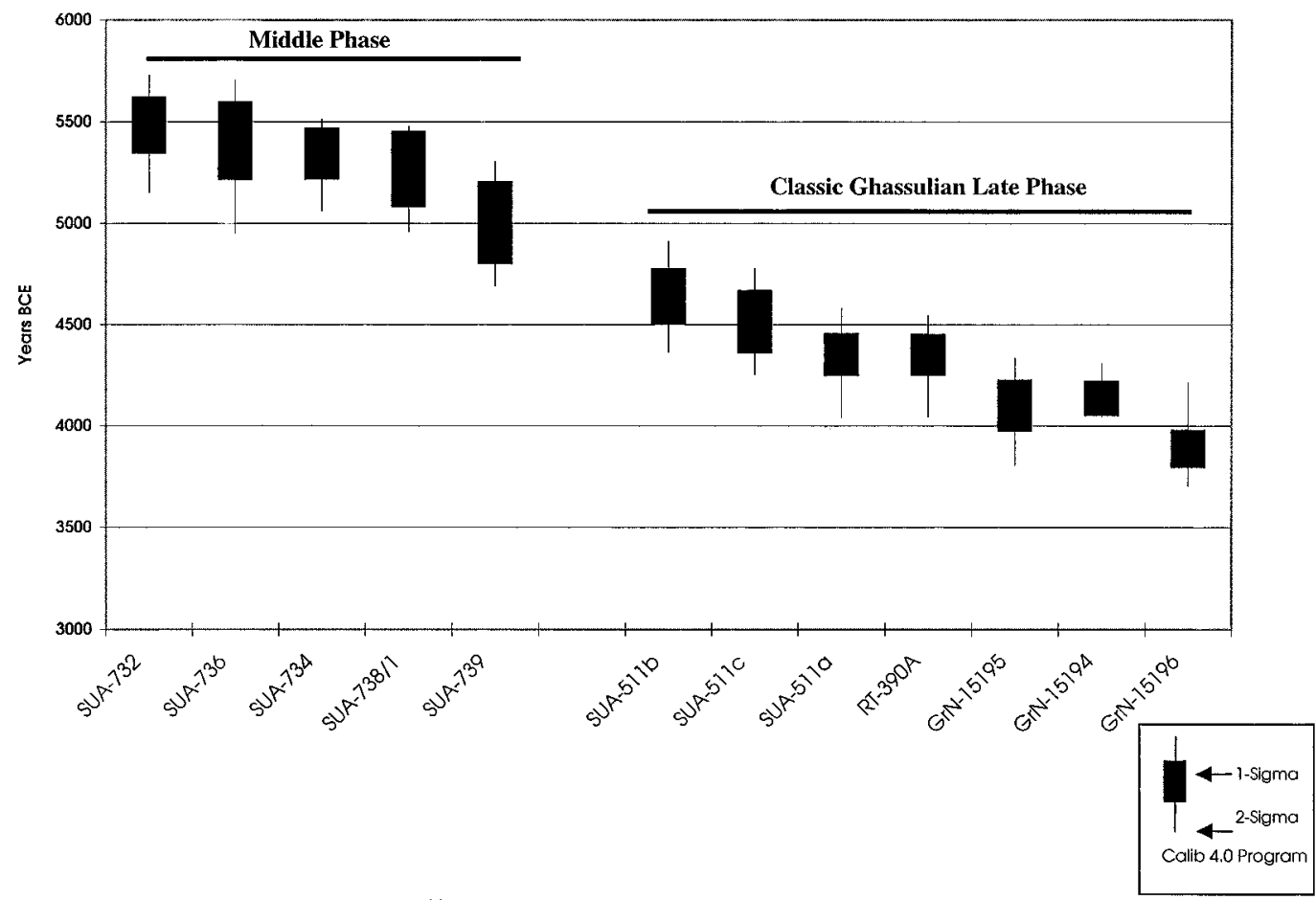

Figure 3 Teleilat Ghassul calibrated ${ }^{14} \mathrm{C}$ dates

Excavations between 1978 and 1993 at Shiqmim, one of the largest Chalcolithic sites in western Palestine, have revealed four main stratigraphic levels corresponding to three principal occupation phases (Levy et al. 1991). Twenty-nine ${ }^{14} \mathrm{C}$ dates, more than from any other Chalcolithic site in Palestine, have been published from all four levels including the system of subterranean rooms and tun- 
nels. Figure 4 shows 27 of these dates, grouped according to stratigraphic level and defined as "Early", "Main", and "Final" occupation phases (after Levy et al. 1991; the two dates not shown in the figure are RT-554B, which has a very large estimate of error, and RT-1329, which falls almost entirely within the 3rd millennium and probably represents later intrusive activity). It should be noted that the available dates from Shiqmim are biased in that Stratum I, the "Final" occupation, is underrepresented. Only four of the 27 dates shown are from this last phase. More ${ }^{14} \mathrm{C}$ dates are needed to clarify the terminus of settlement at Shiqmim which is most likely coincident with the breakdown of northern Negev Chalcolithic societies. A further complication in interpreting Shiqmim dates from the underground room network is that these systems appear to have been frequently re-used, re-configured, and subject to infilling and collapse during and possibly even after the Chalcolithic settlement period (see RT-1329 above). Overall, the lack of a significant chronological break in the current Shiqmim ${ }^{14} \mathrm{C}$ date record shown in Figure 4 suggests continuity of settlement probably occurring within temporal boundaries of about 5500-3300 BCE, conservatively speaking. The ${ }^{14} \mathrm{C}$ dates support the possibility that Shiqmim was part of a regional Chalcolithic settlement system including contemporary polities such as Horvat Beter, Safadi, Abu Matar, Gilat, and other sites yet to be dated with radiometric methods. The corpus of dates also highlights the importance of stratigraphy for defining occupation phases and hence refinements of developmental trajectory. In short, the individual ${ }^{14} \mathrm{C}$ dates alone are too imprecise to distinguish cultural sequencing within less than about a 200 -year period (however, where there are multiple dates from the same archaeological context averaging may help to restrict this range). Detailed typological studies are presently being carried out for Shiqmim and another stratified northern Negev settlement center, Gilat (Alon and Levy, in press). These results may help to explain Chalcolithic social evolutionary processes in the northern Negev region.

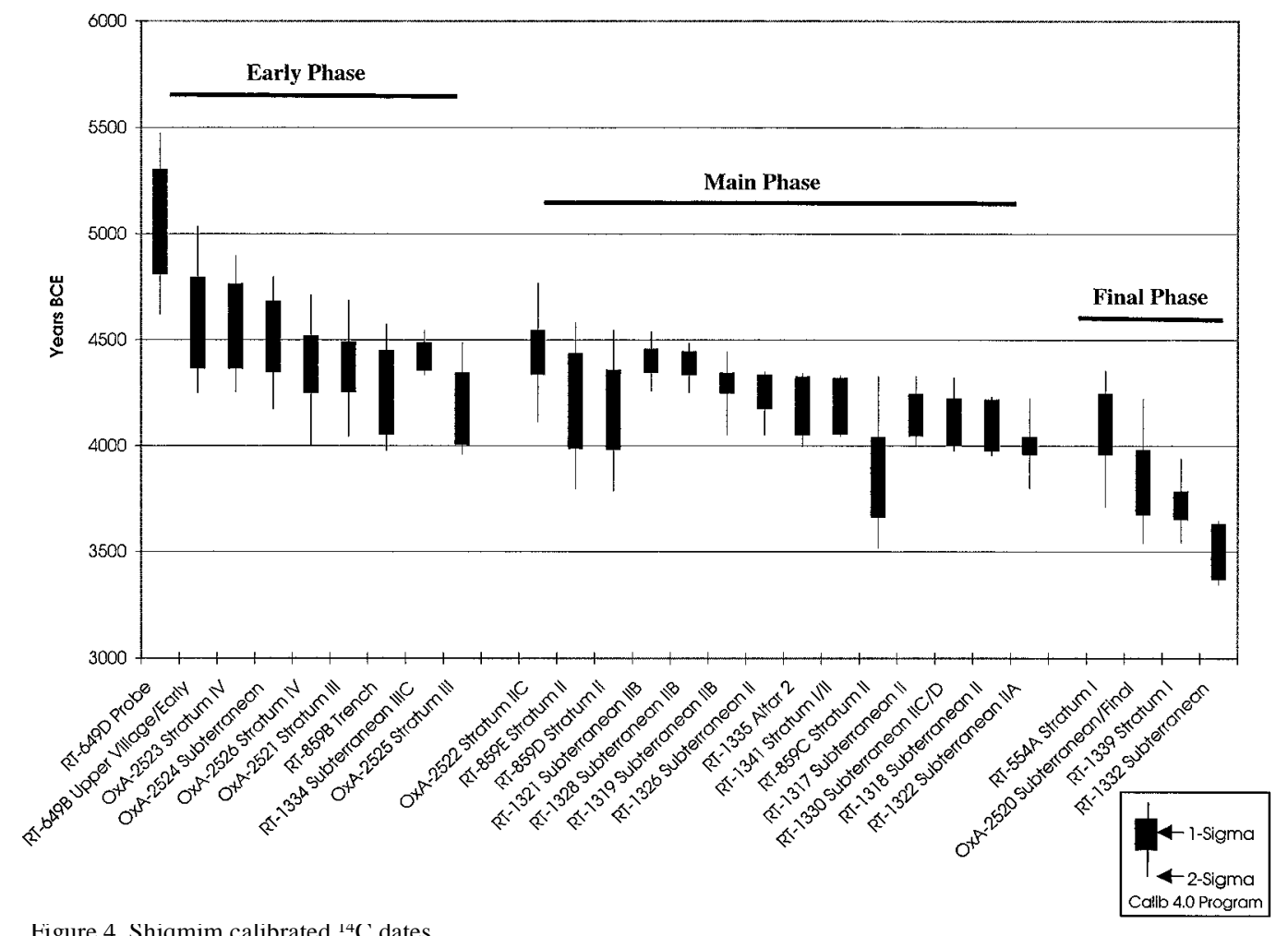

Figure 4 Shiqmim calibrated ${ }^{14} \mathrm{C}$ dates 
Although of limited use within narrow time scales, sets of ${ }^{14} \mathrm{C}$ dates for a number of multi-level Chalcolithic sites, both settlement and burial, suggest possible hypotheses for further research. In this example dates from "early Chalcolithic" or "pre-Ghassulian" contexts as defined by the excavators are not included.

${ }^{14} \mathrm{C}$ boundaries (BCE) for Chalcolithic activity

Settlement Sites

$\mathrm{BCE}$

Abu Hamid (GrN-16358, 17496, 14623)

$4700-4300$

Ghassul(SUA-511a,b,c; RT-390A; GrN-15195, 15194, 15196)

$4900-3700$

Shiqmim (all dates except RT-1329)

$5500-3300$

Burial Caves

Peqi'in Cave (RT-2376, 2377, 2387)

$4500-4000$

Nahal Qanah (RT-861E, 861C, 861A, 1545)

$4500-3500$

Cave of the Warrior (all dates)

$4700-3300$

While the date ranges provide no assurance that human activity was continuous between the end points of the range or indeed occurred at any particular intermediate point, they do bound the possible points of contemporaneity (subject to sampling problems as described above). Thus where there is a lack of overlap we may begin to ask questions such as: What factors may have precipitated the abandonment of Jordan valley Chalcolithic centers Teleilat Ghassul and Abu Hamid by the early 4th millennium while significant occupation at Shiqmim in the Beersheva valley may have endured for several more centuries? Or, why did use of the Peqi'in Cave for elite burials cease by 4000 BCE, possibly 400-700 years before the apparent collapse of Chalcolithic chiefdom societies? The completeness and accuracy of the underlying ${ }^{14} \mathrm{C}$ data base must be verified before proceeding, but it does provide an important foundation for social evolutionary studies.

\section{CONCLUSION}

In this paper we have provided a compilation of currently available ${ }^{14} \mathrm{C}$ dates for the Chalcolithic of the southern Levant. This work builds on the important earlier studies of Gilead (1994), Joffe and Dessel (1995), Lee (1973), and Weinstein (1984). The now-substantial radiometric data base has established general chronological parameters for the Chalcolithic period (ca. 4500-3600 BCE) within which social evolution in the southern Levant may be charted. In addition, the data has significantly contributed to our appreciation of the existence of broadly contemporaneous human settlement across diverse environmental zones at this time. Because these subregions experienced different socioeconomic trajectories reflected in distinctive material traditions, such a finding could not have been supported on the basis of typological parallels alone. Furthermore, and of crucial importance to our understanding of social prehistory, ${ }^{14} \mathrm{C}$ dating has helped to securely placed technological and socio-political innovations connected with the emergence of southern Levantine complex societies within the Chalcolithic era.

It is clear, however, that the large standard deviations observed in ${ }^{14} \mathrm{C}$ dates permit only a gross resolution of cultural sequence. Temporal subphases of the main Chalcolithic period cannot be determined by exclusive appeal to the current radiometric record. More refined evaluations of settlement patterns, social interaction spheres, and developmental trajectories during this protohistoric period depend on stratigraphic and typological analyses, including detailed seriation studies, carried out on a subregional scale. Settlement sites such as Shiqmim and Teleilat Ghassul—with multiple occupation levels, abundant material remains, and stratigraphically controlled excavations-appear to have 
the greatest potential to further delineate patterns of southern Levantine social development and organization within their respective locales during the 5th-4th millennium BCE.

\section{ACKNOWLEDGMENTS}

We thank Stephen J Bourke, University of Sydney, for kindly providing details of the Teleilat Ghassul ${ }^{14} \mathrm{C}$ dates discussed in his 1997 article. We also thank Donald O Henry, University of Tulsa, for clarifying information regarding dates for his sites in southern Jordan. Eliot Braun of the Israel Antiquities Authority discussed new dates relating to the end of the Chalcolithic with us and we are most grateful for his insights on this problematic issue. Graphics for this article were expertly prepared by Adolfo Muniz of the University of California, San Diego Archaeology Lab.

We very much appreciate the financial support of the Judaic Studies Program at the University of California, San Diego for a poster presentation related to this article at the 17th International Radiocarbon Conference in Israel. We also thank the Shelby White-Leon Levy Program for Archaeological Publications for a generous grant to help prepare data from Shiqmim for publication. The research discussed here will be used in conjunction with new Shiqmim ${ }^{14} \mathrm{C}$ determinations for the final site publication.

Finally, we wish to thank the anonymous reviewer whose constructive comments improved the final version of this paper.

\section{REFERENCES}

Aardsma GE. 2001. Redating the Cave of the Treasure Mat. Radiocarbon. This issue.

Adams R, Genz H. 1995. Excavations at Wadi Fidan 4: a Chalcolithic village complex in the Copper Ore District of Feinan, southern Jordan. Palestine Exploration Quarterly 127:8-20.

Aharoni Y. 1962. Expedition B--the Cave of Horror. Israel Exploration Journal 12:186-99.

Alon D, Levy TE, editors. In press. Archaeology, anthropology, and cult: the sanctuary at Gilat (Israel). London: Leicester University Press.

Avner U. 1984. Ancient cult sites in the Negev and Sinai Deserts. Tel Aviv 11:115-31.

Avner U. 1998. Settlement, agriculture and paleoclimate in 'Uvda Valley, Southern Negev Desert, 6th-3rd millennia BC. In: Issar AS, Brown N, editors. Water, environment and society in times of climatic change. Netherlands: Kluwer Academic Publishers. p 147202.

Avner U, Carmi I, Segal D. 1994. Neolithic to Bronze Age settlement of the Negev and Sinai in light of radiocarbon dating: a view from the Southern Negev. In: Bar-Yosef O, Kra RS, editors. Late Quaternary chronology and paleoclimates of the Eastern Mediterranean. Tucson: Radiocarbon, The University of Arizona Board of Regents. p 265-300.

Bar-Adon P. 1980. The Cave of the Treasure: the finds from the caves in Nahal Mishmar. Jerusalem: The Israel Exploration Society.

Bourke SJ. 1997. The "Pre-Ghassulian" sequence at Teleilat Ghassul: Sydney University excavations 19751995. In: Gebel HGK, Kafafi Z, Rollefson GO, editors.
The prehistory of Jordan, II: perspectives from 1997. Studies in Early Near Eastern Production, Subsistence, and Environment 4. Berlin: ex oriente. p 395-417.

Bourke S, Lawson EM, Lovell J, Hua Q, Zoppi U. 2001. The chronology of the Chalcolithic Period in the Southern Levant: new ${ }^{14} \mathrm{C}$ determinations from Teleilat Ghassul, Jordan. Radiocarbon. This issue.

Braun, E. 1996. Cultural diversity and change in the Early Bronze I of Israel and Jordan. Doctoral dissertation. Tel Aviv University.

Carmi I. 1987. Rehovot radiocarbon measurements III. Radiocarbon 29(1):100-14.

Carmi I. 1996. Radiocarbon dates. In: Gopher A, editor. The Nahal Qanah Cave: earliest gold in the Southern Levant. Jerusalem: Graphit Press, Ltd. p 205-8.

Carmi I, Segal D. 1992. Rehovot radiocarbon measurements IV. Radiocarbon 34(1):115-32.

Carmi I, Segal D. 1998. ${ }^{14} \mathrm{C}$ dates from Chalcolithic sites in the Golan. In: Epstein C, editor. The Chalcolithic culture of the Golan. IAA Reports, No. 4. Jerusalem: The Israel Antiquities Authority. p 343.

Dollfus G, Kafafi Z. 1993. Recent researches at Abu Hamid. Annual of the Department of Antiquities of Jordan 37:241-63.

Dothan M. 1959. Excavations at Horvat Beter (Beersheva). 'Atiqot 2:1-71.

Gal Z, Smithline H, Shalem D. 1997. A Chalcolithic burial cave in Peqi' in, Upper Galilee. Israel Exploration Journal 47(3-4):145-54.

Gal Z, Smithline H, Shalem D. 1999. New iconographic aspects of Chalcolithic art: preliminary observations on finds from the Peqi'in Cave. 'Atiqot 37:1-16. 
Gilead I. 1988. The Chalcolithic period in the Levant. Journal of World Prehistory 2(4):397-443.

Gilead I. 1994. The history of the Chalcolithic settlement in the Nahal Beer Sheva area: the radiocarbon aspect. Bulletin of the American Schools of Oriental Research 296:1-13.

Gopher A, Gophna R. 1993. Cultures of the eighth and seventh millennia BP in the Southern Levant: a review for the 1990s. Journal of World Prehistory 7(3):297353.

Gopher A. 1996. The Nahal Qanah Cave: earliest gold in the Southern Levant. Jerusalem: Graphit Press, Ltd.

Gophna R. 1998. Early Bronze Age Canaan: some spatial and demographic observations. In: Levy TE, editor. The archaeology of society in the Holy Land. 2nd edition. New York: Facts on File, Inc. 269-81.

Hedges REM, Housley RA, Bronk CR, van Klinken GJ. 1992. Radiocarbon dates from the Oxford AMS system. Archaeometry 34:337-57.

Henry DO. 1992. Seasonal movements of fourth millennium pastoral nomads in the Wadi Hisma, Southern Jordan. In: Zaghloul M, 'Amr K, editors. History and archaeology of Jordan. Vol. 4. Amman: Department of Antiquities. p 137-43.

Henry DO. 1995. Prehistoric cultural ecology and evolution: insights from Southern Jordan. New York: Plenum Press.

Housley RA. 1994. Eastern Mediterranean chronologies: the Oxford AMS contribution. In: Bar-Yosef O, Kra RS, editors. Late Quaternary chronology and paleoclimates of the Eastern Mediterranean. Tucson:Radiocarbon, The University of Arizona. p 55-73.

Joffe AH, Dessel JP. 1995. Redefining chronology and terminology for the Chalcolithic of the Southern Levant. Current Anthropology 36(3):507-18.

Jull AJT, Donahue DJ, Carmi I, Segal D. 1998. Radiocarbon dating of finds. In: Schick T, editor. The Cave of the Warrior: A fourth millennium burial in the Judean Desert. IAA Reports, No. 5. Jerusalem: The Israel Antiquities Authority. p 110-2.

Kaplan J. 1969. 'Ein el Jarba: Chalcolithic remains in the Plain of Esdraelon. Bulletin of the American Schools of Oriental Research 194:2-39.

Kozloff B. 1974. A brief note on the lithic industries of Sinai. Museum Haaretz Yearbook 15-16: 35-49.

Lee J. 1973. Chalcolithic Ghassul: new aspects and master typology. Doctoral dissertation. The Hebrew University of Jerusalem.

Levy TE, Adams RB, Witten AJ, Anderson J, Arbel Y, Kuah S, Moreno J, Lo A, Wagonner M. In press. Early metallurgy, interaction, and social change: the Jebal Hamrat Fidan (Jordan) research design and 1998 archaeological survey: preliminary report. In: Bisheh G. editor. Proceedings of the 7th International Conference on the Archaeology of Jordan. Copenhagen 1998. Studies in the History and Archaeology of Jordan.

Levy TE, Alon D. 1987. Excavations in the Shiqmim Village. In: Levy TE, editor. Shiqmim I: studies concern- ing Chalcolithic societies in the Northern Negev Desert, Israel. Oxford: BAR International Series 356(i). p 373-411.

Levy TE, Alon D, Grigson C, Holl A, Goldberg P, Rowan Y, Smith P. 1991. Subterranean Negev settlement. National Geographic Research \& Exploration 7(4):394413.

Levy TE, Alon D, Rowan Y, van den Brink ECM, Grigson C, Holl A, Smith P, Goldberg P, Witten AJ, Kansa E, Moreno J, Yekuteili Y, Porat N, Golden J, Dawson L, Kersel M. 1997. Egyptian-Canaanite interaction at Nahal Tillah, Israel (ca. 4500-3000 BCE): an interim report on the 1994-1995 excavations. Bulletin of the American Schools of Oriental Research 307:1-51.

Lovell J, Kafafi Z, Dollfus G. 1997. A preliminary note on the ceramics from the basal levels of Abu Hamid. In: Gebel HGK, Kafafi Z, Rollefson GO, editors. The Prehistory of Jordan, II. Perspectives from 1997. Studies in Early Near Eastern production, subsistence, and environment 4. Berlin: ex oriente. p 361-370.

Marcus J, Feinman GM. 1998. Introduction. In: Feinman GM, Marcus J, editors. Archaic states. Santa Fe: School of American Research Press. p 3-14.

Mellaart J. 1979. Egyptian and Near Eastern chronology: a dilemma? Antiquity 53:6-19.

Najjar M, Abu Dayya A, Suleiman E, Weisgerber G, Hauptmann A. 1990. Tell Wadi Feinan: the first pottery Neolithic Tell in the south of Jordan. Annual of the Department of Antiquities of Jordan 34:27-56.

Perrot J. 1987. Introduction. In: Commenge-Pellerin C. La poterie d'Abou Matar et de l'Ouadi Zumeili (Beersheva) au IVe millenaire avant l'ere Chretienne. Les Cahiers du Centre de Recherche Francais de Jerusalem 3. Paris: Association Paleorient. p 15-7.

Rosen SA. 1984. Kvish Harif: preliminary investigation at a Late Neolithic site in the central Negev. Paleorient 10(2):111-21.

Rothenberg B, Glass J. 1992. The beginnings and the development of early metallurgy and the settlement and chronology of the western Arabah, from the Chalcolithic Period to Early Bronze Age IV. Levant 24: 141-57.

Schick T, editor. 1998. The Cave of the Warrior: a fourth millennium burial in the Judean Desert. IAA Reports, No. 5. Jerusalem: The Israel Antiquities Authority.

Segal D, Carmi I. 1996. Rehovot radiocarbon date list V. 'Atiqot 29:79-106.

Segal D, Carmi I, Gal Z, Smithline H, Shalev D. 1998. Dating a Chalcolithic burial cave in Peqi'in, Upper Galilee, Israel. Radiocarbon 40(2):707-12.

Stuiver M, Reimer PJ, Bard E, Beck JW, Burr GS, Hughen KA, Kromer B, McCormac G, van der Plicht J, Spurk M. 1998. INTCAL98 radiocarbon age calibration, 24,000-0 BP. Radiocarbon 40(3):1041-84. (http://depts.washington.edu/qil)

Weinstein JM. 1984. Radiocarbon dating in the Southern Levant. Radiocarbon 26(3):297-366 


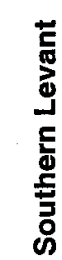

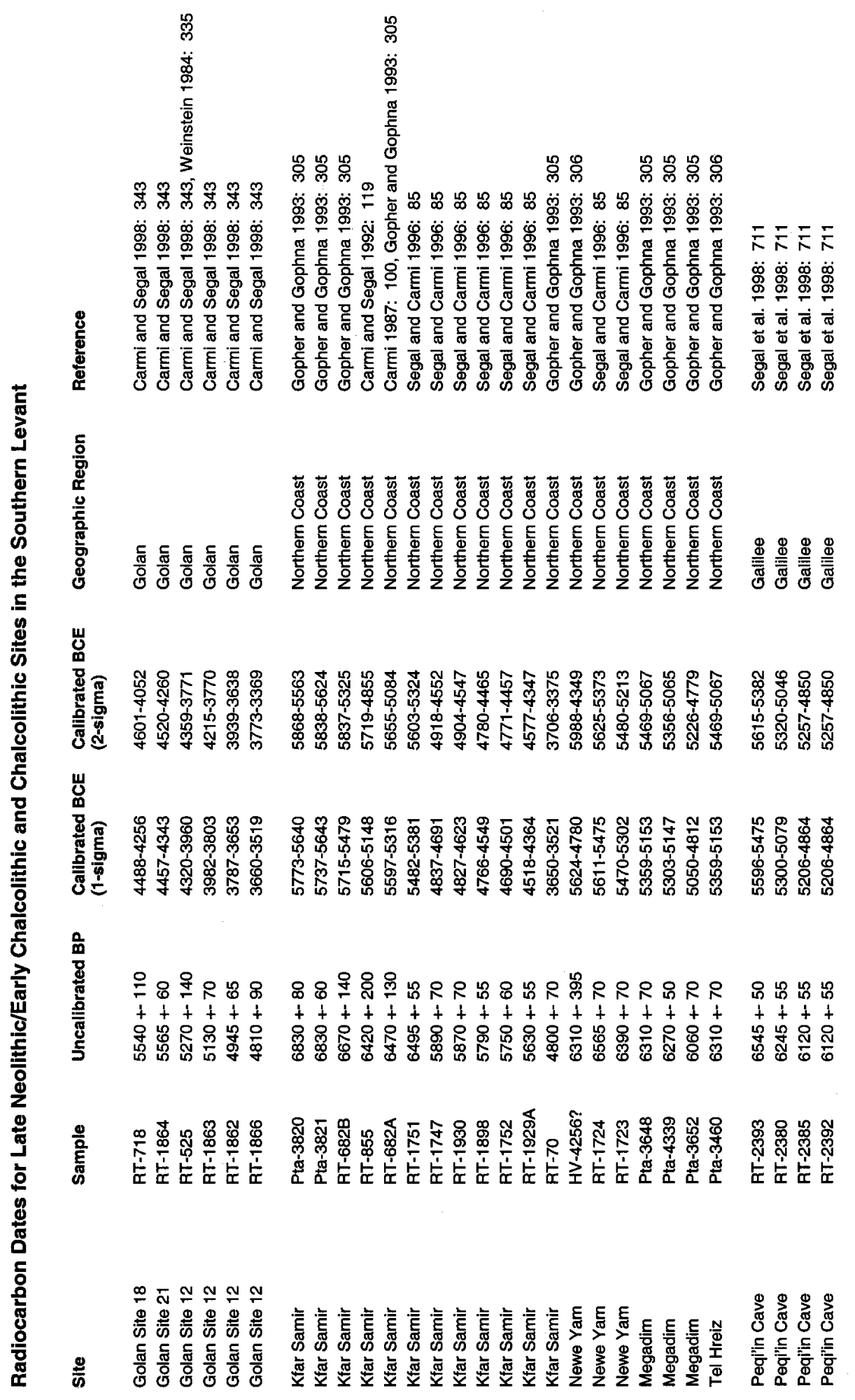




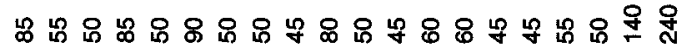
$t+t+t+t+t+t+t+t+t+t+$ 员 $80.0 \%$

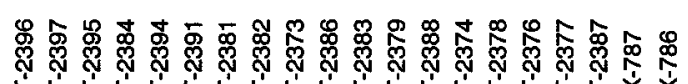

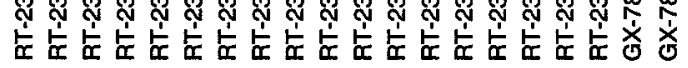

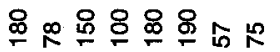
$+t+t+t+t$

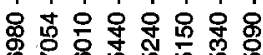

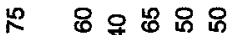
$+\quad+t+t$ 突

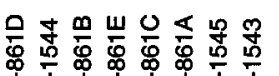

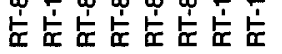

单

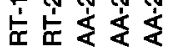

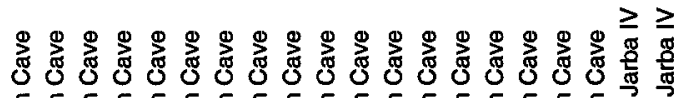

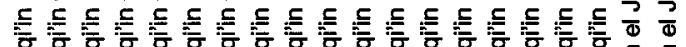

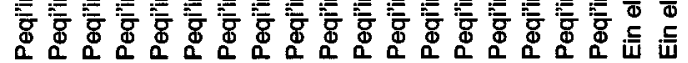

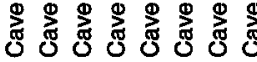

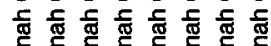

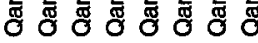

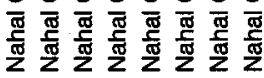




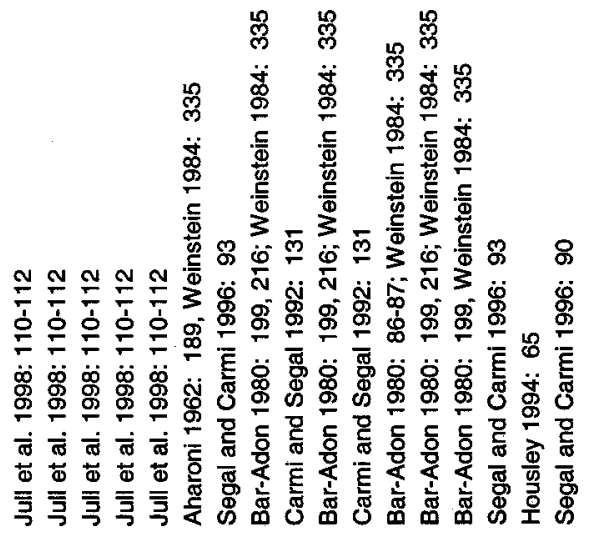

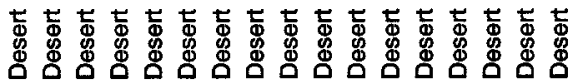

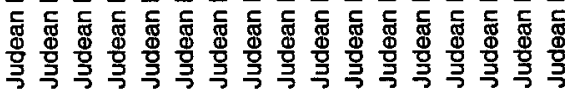

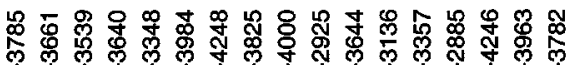

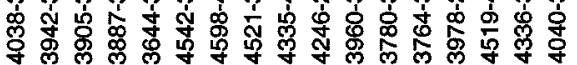

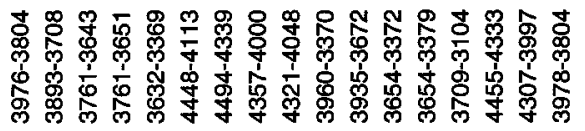

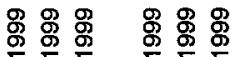

흘 흘 흥 흘 흘

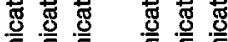

突 壱

安

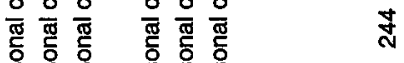

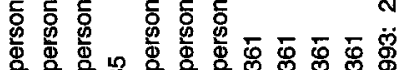

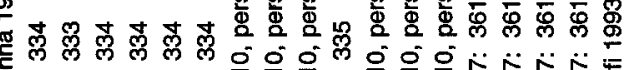

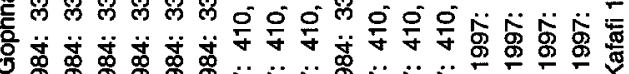

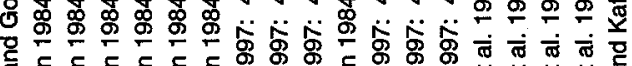

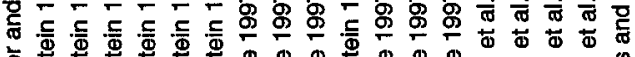

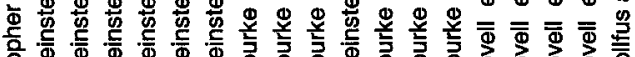
mons

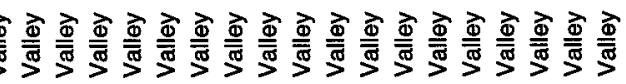

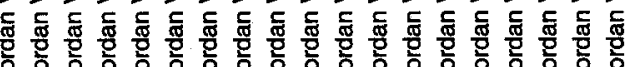

Mins

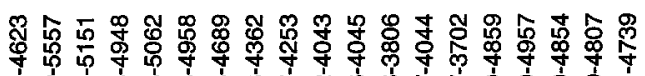

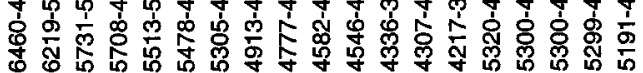

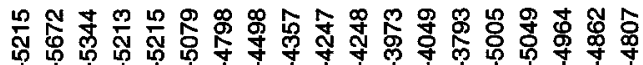

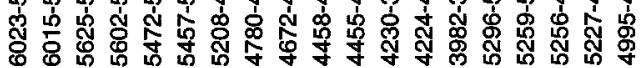

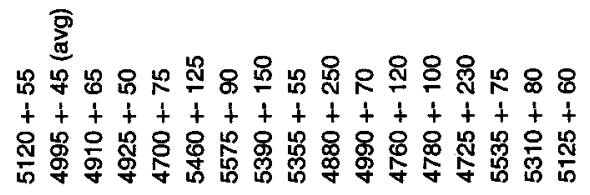

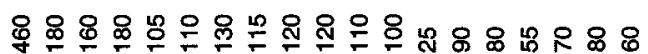
$t+t+t+t+t+t+t+t+t+t$

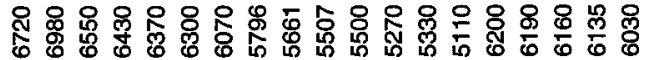

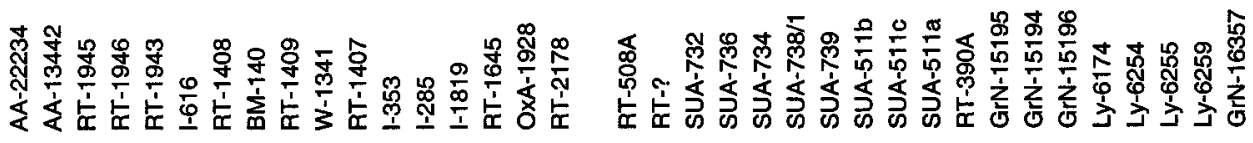

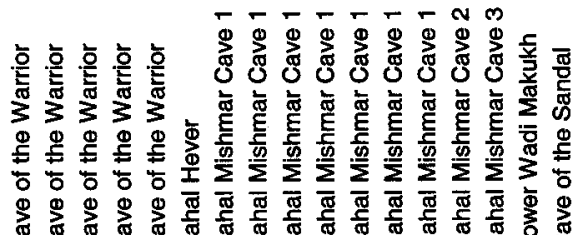

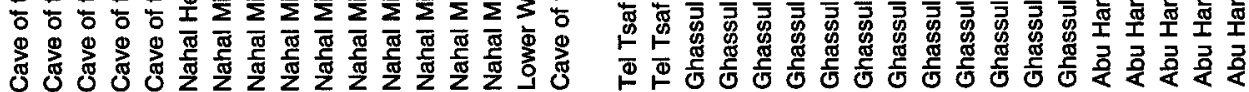




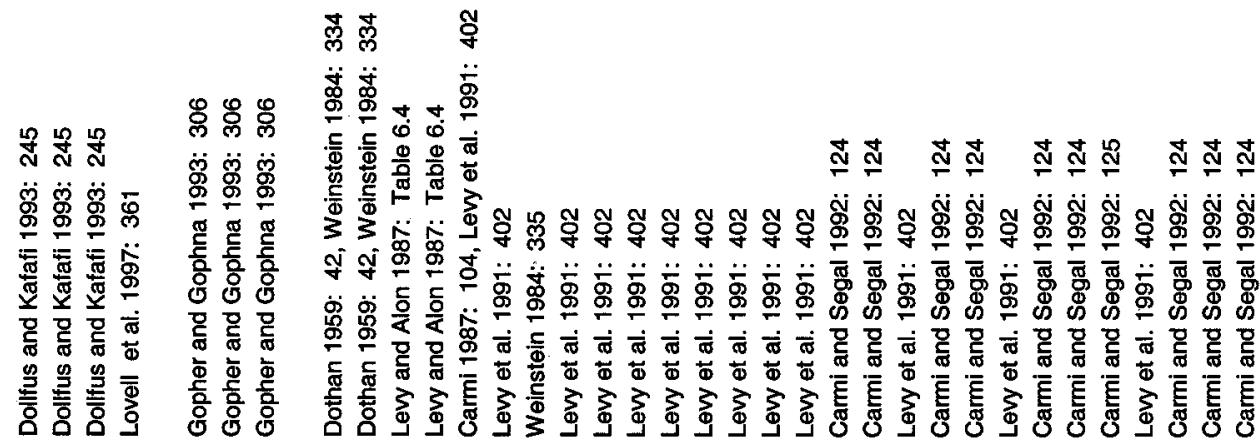

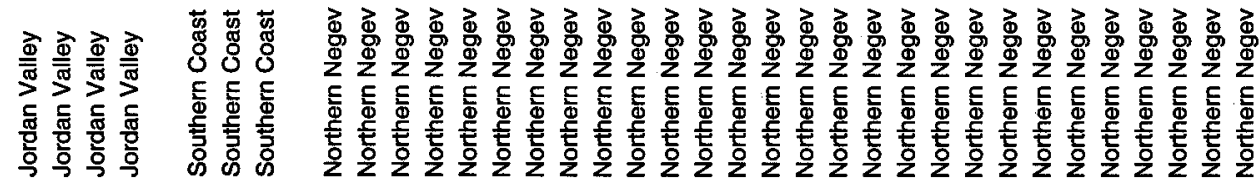

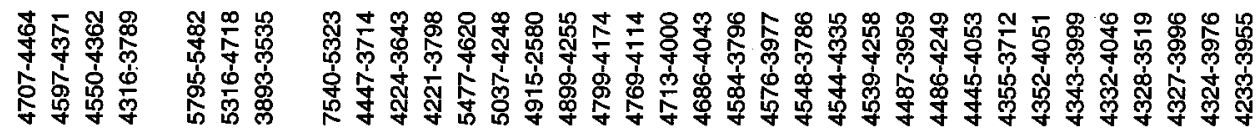

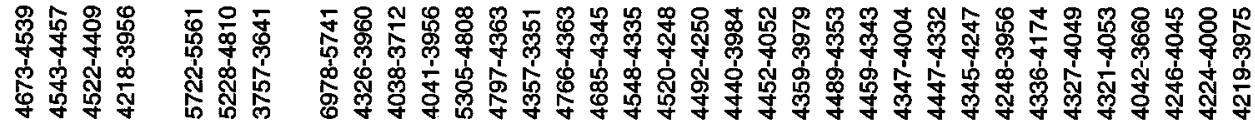

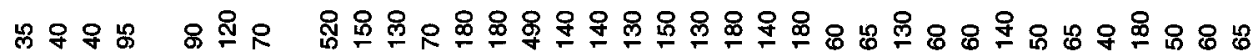

$+t+t+t+t+t+t+t+t+t+t+t+t+t+t+t+t+t+t+$

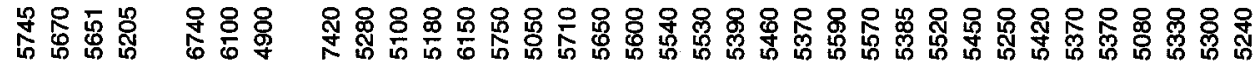

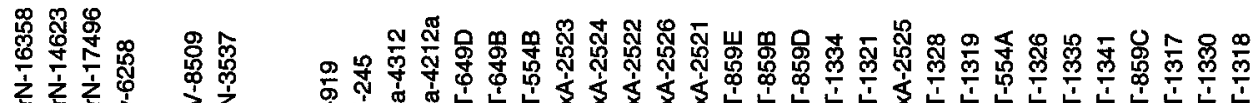

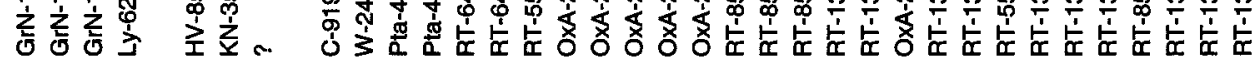

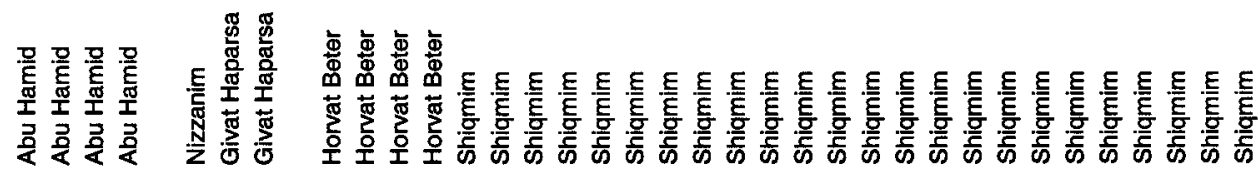




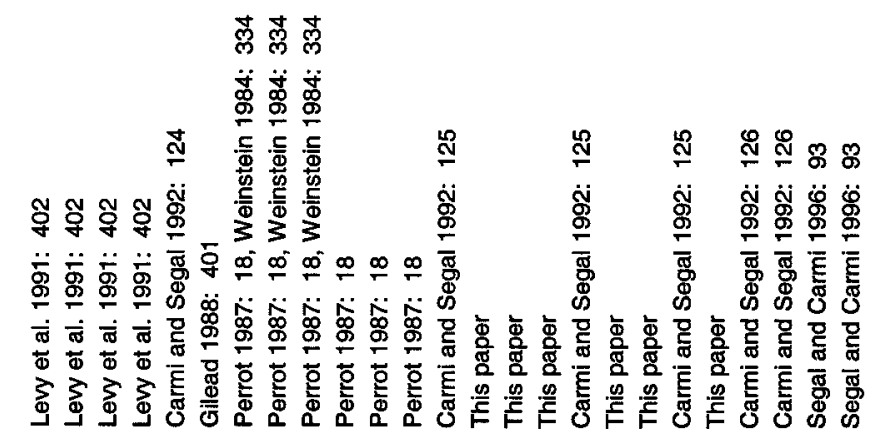

ल्ले ल्ल है

䓞楞兽

๘ं

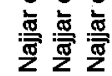

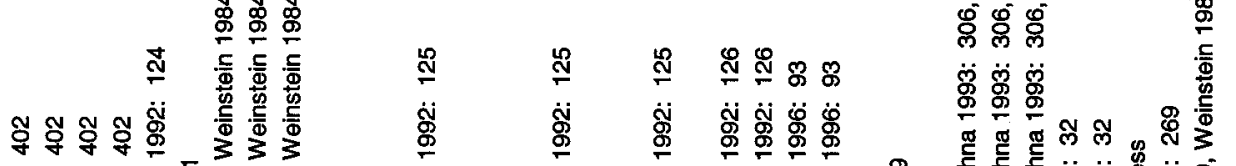

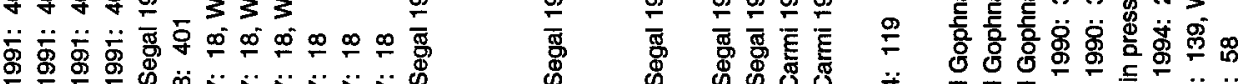

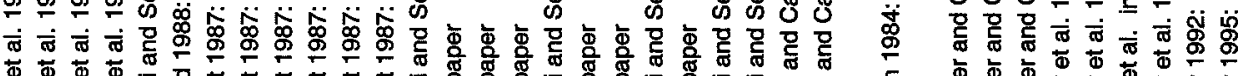

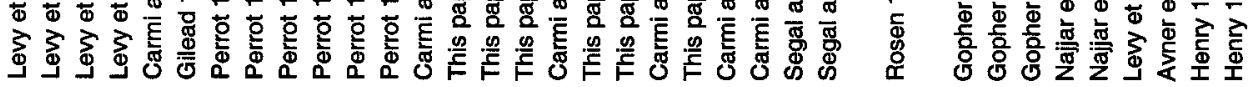
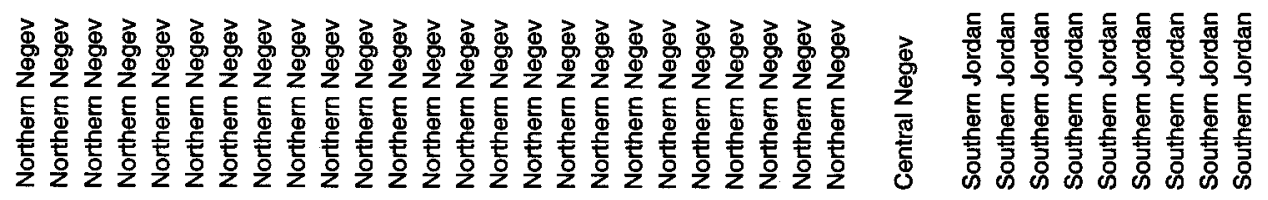

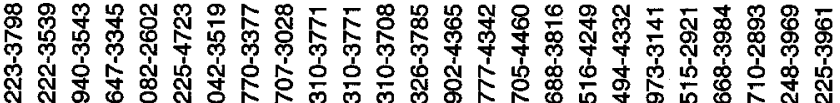

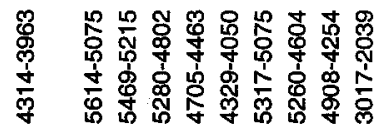

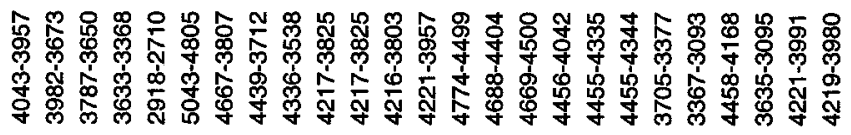

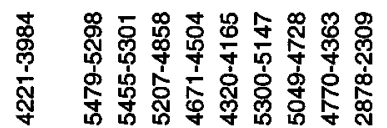

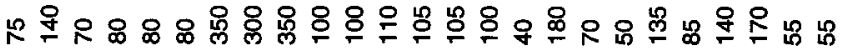
$t+t+t+t+t+t+t+t+t+t+t+t+t+$

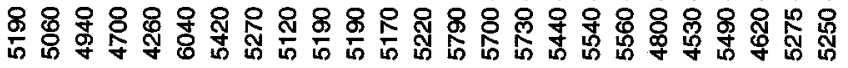

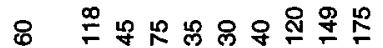
$t+t+t+t+t+$

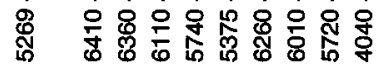

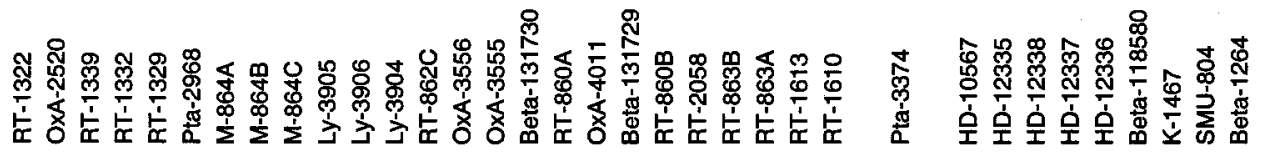

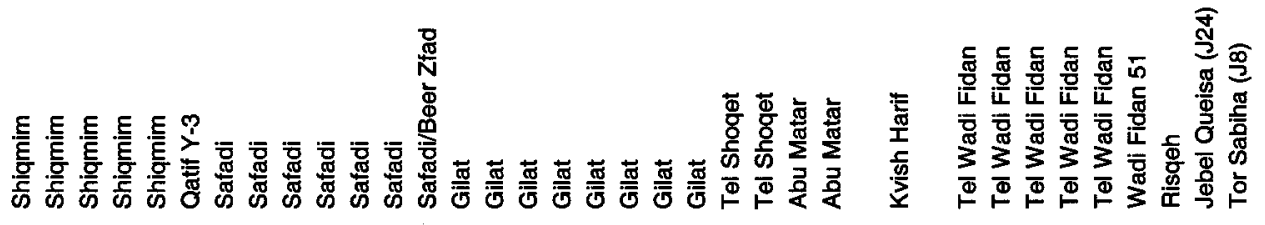




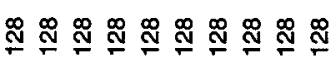

总兽兽

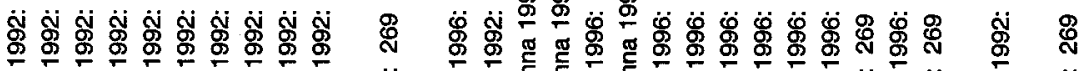

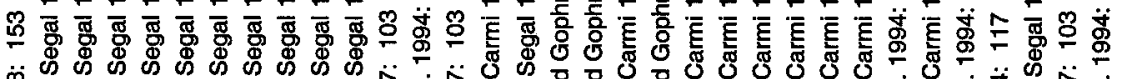
㒸出

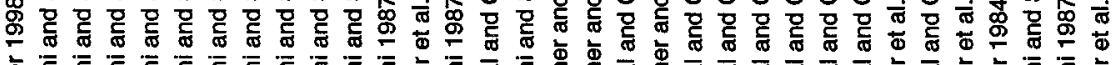

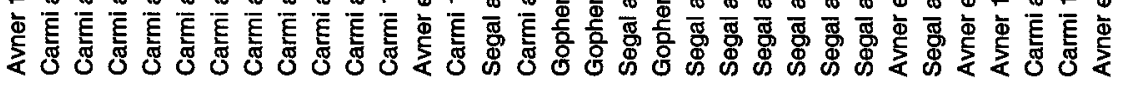

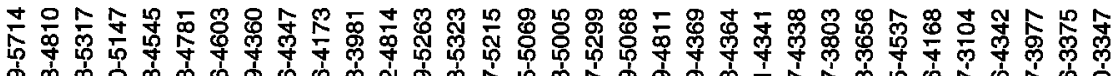

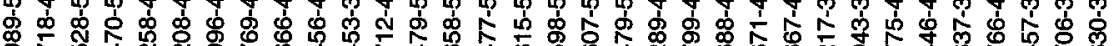

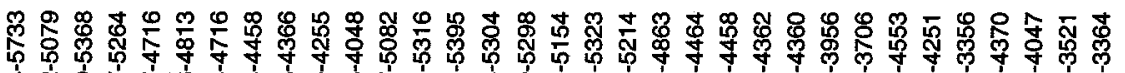

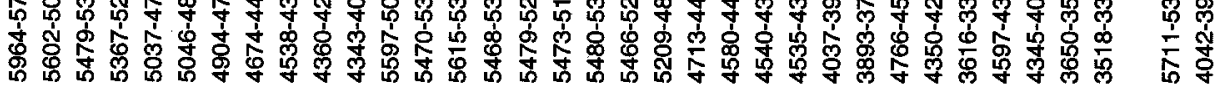

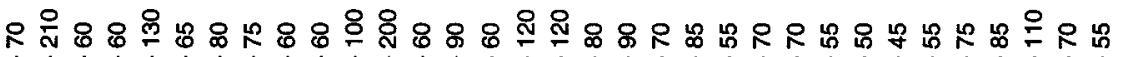

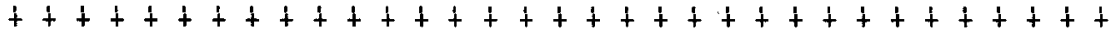

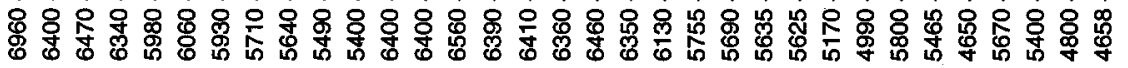

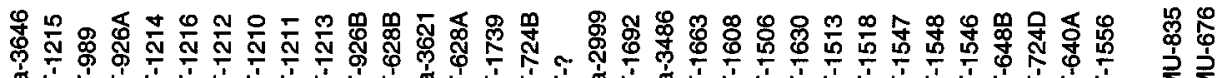

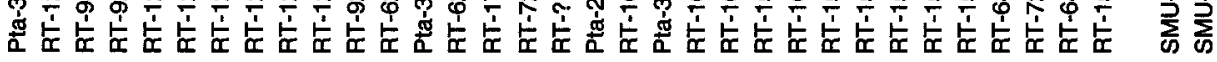

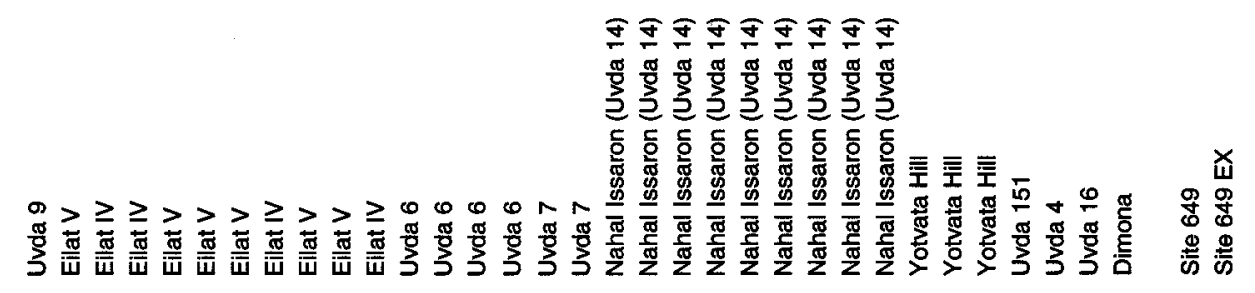




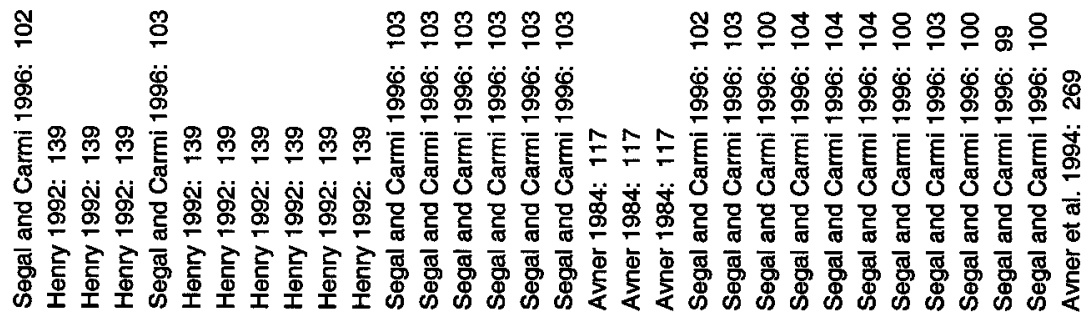

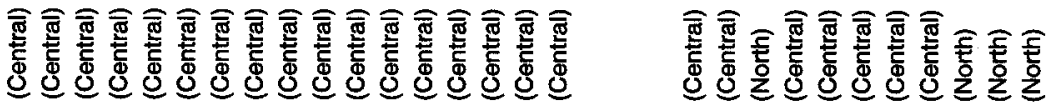

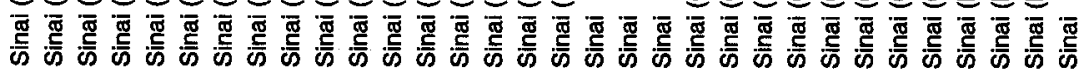

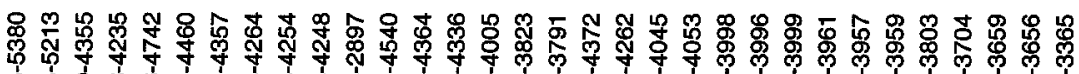

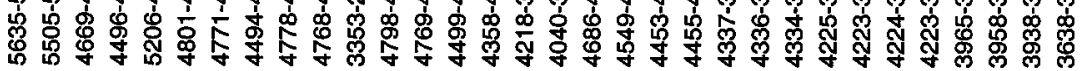

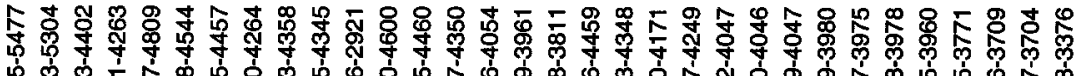

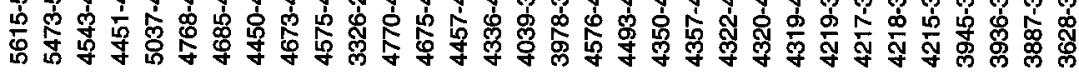

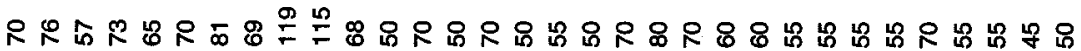
$+t+t+t+t+t+t+t+t+t++t++t+t+t+t+t$

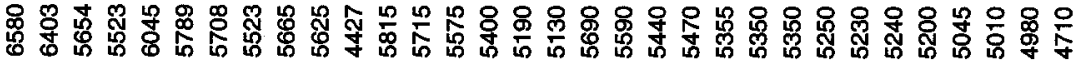

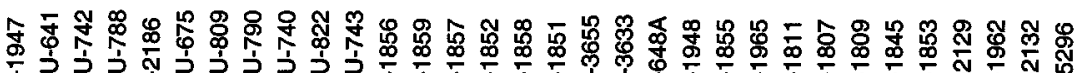

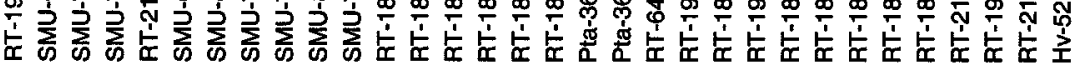

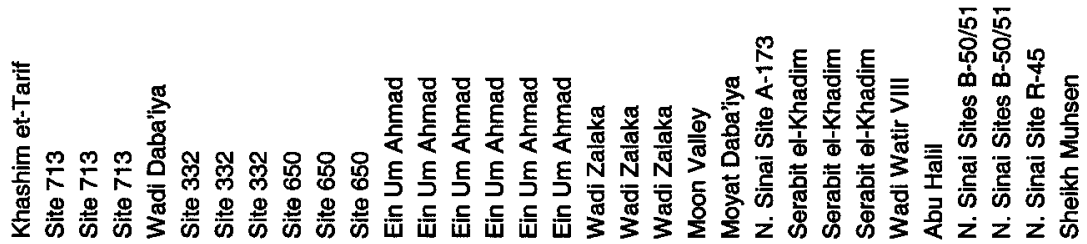

